\title{
Chromosomal aberrations in head and neck squamous cell carcinomas in Norwegian and Sudanese populations by array comparative genomic hybridization
}

\author{
ERIC ROMAN ${ }^{1,2}$, LEONARDO A. MEZA-ZEPEDA ${ }^{3}$, STINE H. KRESSE ${ }^{3}$, \\ OLA MYKLEBOST $^{3,4}$, ENDRE N. VASSTRAND ${ }^{2}$ and SALAH O. IBRAHIM ${ }^{1,2}$ \\ ${ }^{1}$ Department of Biomedicine, Faculty of Medicine and Dentistry, University of Bergen, Jonas Lies vei 91; \\ ${ }^{2}$ Department of Oral Sciences - Periodontology, Faculty of Medicine and Dentistry, University of Bergen, \\ Årstadveien 17, 5009 Bergen; ${ }^{3}$ Department of Tumor Biology, Institute for Cancer Research, \\ Rikshospitalet-Radiumhospitalet Medical Center, Montebello, 0310 Oslo; ${ }^{4}$ Department of \\ Molecular Biosciences, University of Oslo, Blindernveien 31, 0371 Oslo, Norway
}

Received January 30, 2008; Accepted April 29, 2008

DOI: $10.3892 /$ or_00000080

\begin{abstract}
We used microarray-based comparative genomic hybridization to explore genome-wide profiles of chromosomal aberrations in 26 samples of head and neck cancers compared to their pair-wise normal controls. The samples were obtained from Sudanese $(n=11)$ and Norwegian $(n=15)$ patients. The findings were correlated with clinicopathological variables. We identified the amplification of 41 common chromosomal regions (harboring 149 candidate genes) and the deletion of 22 (28 candidate genes). Predominant chromosomal alterations that were observed included high-level amplification at 1q21 (harboring the S100A gene family) and 11q22 (including several $M M P$ family members). Regions of copy number increase was also identified at 6p21 (p21), 7p12 (EGFR), $17 \mathrm{p} 13$ (p53) and 19p13.2 (p19 INK4d), while regions showing deletion included among others 3p25.2 (RAF1) and 9p21 $(p 15, p 16)$. We found genes from four common biological pathways (MAPK signaling, cytokine-cytokine receptor interaction, ECM-receptor interaction and Jak-STAT signaling) to be predominantly over-represented in areas of gain and loss. The current study provides valuable information on chromosomal aberrations likely to be involved in the pathogenesis of head and neck cancers. An increased copy number of the $S 100 A$ and $M M P$ gene family members, known to be involved in invasion and metastasis, may play an important role in the development of the tumors. Hierarchical clustering of the chromosomal alterations with clinicopatho-
\end{abstract}

Correspondence to: Dr Eric Roman, Department of Biomedicine, Faculty of Medicine and Dentistry, University of Bergen, Jonas Lies vei 91, 5009 Bergen, Norway

E-mail: eric.roman@biomed.uib.no

Key words: microarray-based comparative genomic hybridization, squamous cell carcinoma, genetic aberration, Sudan, Norway logical parameters showed little correlation, suggesting an occurrence of gains/losses regardless of ethnic differences and clinicopathological status between the patients from the two countries. Our findings indicate the existence of common gene-specific amplifications/deletions in these tumors, regardless of the source of the samples or attributed carcinogenic risk factors.

\section{Introduction}

Head and neck squamous cell carcinoma (HNSCC), including the oral squamous cell carcinoma (OSCC) subtype, is an aggressive disfiguring disease characterized by events of heterogeneous chromosomal/genetic alterations influencing growth, proliferation and differentiation of the cells (1). The main etiological factors related to the development of HNSCCs involve the use of tobacco and alcohol consumption (2-5). While the incidence of HNSCCs in industrial countries seems to be related to cigarette smoking and alcohol consumption, the use of smokeless tobacco is suggested to be the main carcinogenic risk factor in developing countries. Although social habits of cigarette smoking and alcohol consumption are common in Norway, the incidence rate of HNSCCs reported in the period 1996-2001 has been rather low, affecting $6.1 \%$ of male and $2.5 \%$ of female patients (6). Due to cultural and religious constraints, cigarette smoking and alcohol consumption are not common in Sudan and the high incidence of HNSCCs reported in that country (11.6\% for males and $6.91 \%$ for females) is attributed to the extensive use of the locally produced, highly carcinogenic smokeless tobacco, locally known as toombak (7).

Microarray-based comparative genomic hybridization (array CGH) is a powerful method that allows detection and analysis of chromosomal copy number changes (gains/losses) at a high resolution throughout the genome $(8,9)$. Contrary to the conventional CGH that is limited by its resolution, array CGH can be used to capture chromosomal changes at levels of 5-10 kb of the DNA sequence, including the detection of 
microamplifications and microdeletions $(10,11)$. CGH studies of head and neck squamous cell carcinoma, including HNSCCs, have previously identified gains of chromosomal regions at 1q21, 3q26.3, 5p15, 7p12, 8q24, 9q34, 11q13 and 20q12, and deletions of 3p, 4q, 5q, 7q22, 8p23, 9p21, 13q12$24,17 \mathrm{p}, 18 \mathrm{q} 21,21 \mathrm{q} 11-21$ and $22 \mathrm{q}$ (12). The loss of heterozygosity $(\mathrm{LOH})$ and several regions of deletions of the short arm of chromosome 3 and 9, as well as frequent deletions at $8 p, 17 p, 13 q$ and $9 p$, represent some of the earlier events of the development and progression of the HNSCCs (9). It has been suggested that chromosomal gains detected at 3q26 and $11 \mathrm{q} 13$ and deletions of 8 p23 and 22q may be associated with the high aggressiveness status of HNSCCs $(13,14)$.

In the present study, we applied array CGH to investigate genome-wide profiles of chromosomal aberrations in HNSCCs compared to their pair-wise controls from Sudan $(n=11)$ and Norway $(n=15)$, using genomic microarrays with $1 \mathrm{Mb}$ resolution. The findings were correlated with clinicopathological data.

\section{Materials and methods}

Patients and tissue specimens. Tissue samples of 26 tumors and their pair-wise normal controls were obtained from Sudanese $(n=11)$ and Norwegian $(n=15)$ patients, clinically diagnosed with HNSCCs. Samples from Sudan were obtained from the Department of Oral and Maxillofacial Surgery at the Khartoum University Dental Teaching Hospital, Khartoum, Sudan. Samples from Norway were obtained from the Department of Otolaryngology/Head and Neck Surgery at the Haukeland University Hospital, Bergen, Norway. For Sudan, the study was evaluated and approved by the Medical Ethics Committee at the University of Khartoum and for Norway the study was approved by the Regional Committee for Medical Ethics at Haukeland University Hospital, Bergen, Norway.

Immediately after surgery, the biopsies were submerged in the tissue storage and RNA stabilization solution, RNALater ${ }^{\mathrm{TM}}$ (Ambion, Applied Biosystems, 850 Lincoln Center Dr., Foster City, CA, USA) and stored at $-20^{\circ} \mathrm{C}$. Tumors were staged according to the 1987 Unio Internationale Contra Cancrum (UICC) staging system. Using haematoxylin and eosin (H\&E) for the staining of fresh-frozen or $10 \%$ formalin-fixed, paraffin-embedded tissue sections, a histopathological diagnosis was performed at the Department of Oral Pathology, Dental Faculty Haukeland University Hospital, Bergen, Norway. Tumors were histopathologically graded into high $(\mathrm{H})$, moderate $(\mathrm{M})$ and poorly $(\mathrm{P})$ differentiated according to Cawson and Eveson (15) (Table I). Each tumor sample was confirmed to contain $\geq 70 \%$ of cancer cells and $<10 \%$ necrotic tissue to avoid stromal cell contamination.

Clinicopathological data, including the anatomical site of the tumor, age, gender, differentiation status, tumor stage in the patients and social habits of cigarette smoking/use of smokeless tobacco and alcohol consumption, are shown in Table I. For the two countries, the use of smokeless tobacco and cigarette smoking was quantified and patients were grouped into non-smokers (NS), light smokers (LS: 1-10 cigarettes/day), moderate smokers (MS: 11-20 cigarettes/day) and heavy smokers (HS: $>20$ cigarettes/day). The patients were grouped according to their habit of alcohol consumption into non-drinkers (ND), light drinkers (LD: 1-2 drinks/day), moderate drinkers (MD: 3-5 drinks/day) and heavy drinkers (HD: $>5$ drinks/day) (Table I). The distribution (\%) of the clinicopathological characteristics in patients diagnosed with HNSCC from Sudan and Norway is given in Table II.

Array $C G H$. The genomic microarray that was used contained 4,549 bacterial- and P1 artificial chromosome (BAC and $\mathrm{PAC}$ ) clones representing the human genome at $\sim 1 \mathrm{Mb}$ resolution, as well as the minimal tiling-path between 1q12q25. The microarrays were provided by the Norwegian Microarray Consortium (NMC, www microarray.no).

Tissue samples of the tumor and normal controls were removed from the RNALater storage solution and genomic DNA was extracted using a DNeasy purification kit (Qiagen Inc, Valencia, CA, USA) according to the manufacturer's instructions. Array-CGH was performed as described previously (49). In brief, $500 \mathrm{ng}$ genomic DNA purified from tumor and normal control DNA were digested with DpnII (New England Biolabs, Ipswich, MA, USA). Tumor DNA was labeled with Cy3-dCTP and normal control DNA with Cy5-dCTP (NEN Life Science Products Inc., Boston, MA, USA) by random priming. The labeled DNA samples were combined and mixed with $135 \mu \mathrm{g}$ human Cot-1 DNA (Roche Diagnostics Corp., Indianapolis, IN, USA). Hybridization was performed using an automated hybridization station, GeneTAC/HybArray (Genomic Solutions, Ann Arbor, MI, USA) with agitation for $42 \mathrm{~h}$ at $37^{\circ} \mathrm{C}$. The arrays were scanned using an Agilent G2565B scanner (Agilent Technologies Inc., Santa Clara, CA, USA).

Array $C G H$ data analysis. Images were analyzed using GenePix Pro 3.1 software (Molecular Devices Corp., Sunnyvale, CA, USA). Further data processing, including filtering and normalization, was performed as previously described using M-CGH, a MATLAB toolbox designed for the analysis of array CGH experiments $(16,17)$. Detailed clone information, chromosomal regions, gene content and genes involved in various forms of cancer were accessed using the Ensembl (http://www .ensembl.org), GeneCards ${ }^{\circledR}$ (http:// www.genecards.org) and The Cancer Genome Anatomy Project - CGAP (http://cgap.nci.nih.gov/) databases.

For the detection of chromosomal regions showing gains/ losses common for the two populations, CGH-Explorer software was used (http://www.ifi.uio.no/forskning/grupper/ bioinf/Papers/CGH). Alterations of specific chromosomal regions $>0.3$ and $<-0.3$ on $\log _{2}$ scale found in a minimum of $20 \%$ of the Sudanese and Norwegian patients were considered for further investigation.

Furthermore, we investigated chromosomal alterations (gains/losses) for each population separately. Chromosomal regions that were found to be either amplified or deleted in a minimum of $18 \%$ of one population were expected not to show any alterations in the other population. We performed an analysis of the panel of all genes located in regions of chromosomal gains/losses in respect to their possible involvement in biological pathways using Kyoto Encyclopedia of Genes and Genomes - KEGG (http://www. kegg.com).

Hierarchical clustering of the chromosomal gains and losses found in the tumors examined from patients from Sudan 
Table I. Clinicopathological parameters of the patients diagnosed with the OSCCs.

\begin{tabular}{|c|c|c|c|c|c|c|c|}
\hline Tumor no./site & Age & Gender & H.D. & TNM & Tobacco & Alcohol & Snuff \\
\hline \multicolumn{8}{|l|}{ Sudanese cases } \\
\hline 15/Buccal & 55 & M & $\mathrm{H}$ & T3N0M0 & NS & MD & Yes \\
\hline 17/Plate & 55 & M & $\mathrm{H}$ & T3N1M0 & NS & ND & No \\
\hline 32/Tongue & 75 & $\mathrm{~F}$ & M & T3N1M0 & NS & ND & No \\
\hline 44/Buccal & 65 & M & $\mathrm{H}$ & T3N1M0 & NS & MD & Yes \\
\hline $50 /$ Floor of mouth & 70 & $\mathrm{~F}$ & $\mathrm{P}$ & T3N1M0 & NS & ND & Yes \\
\hline 51/Gingiva & 56 & M & $\mathrm{P}$ & T3N1M0 & NS & ND & No \\
\hline $52 /$ Floor of mouth & 66 & M & M & T2N1M0 & NS & ND & No \\
\hline 59/Buccal & 60 & M & $\mathrm{P}$ & T2N1M0 & MS & ND & No \\
\hline 63/Tongue & 75 & $\mathrm{~F}$ & M & T2N1M0 & NS & ND & No \\
\hline 65/Buccal & 75 & $\mathrm{~F}$ & M & T2N1M0 & NS & ND & No \\
\hline 69/Buccal & 34 & M & $\mathrm{H}$ & T2N1M0 & NS & ND & No \\
\hline \multicolumn{8}{|l|}{ Norwegian cases } \\
\hline 17/Gingiva & 65 & $\mathrm{~F}$ & $\mathrm{H}$ & T3N0M0 & MS & ND & nd \\
\hline 21/Larynx & 60 & M & M & T2N0M0 & MS & nd & nd \\
\hline 23/Tongue & 31 & M & $\mathrm{H}$ & T2N0M0 & NS & nd & nd \\
\hline 39/Gingiva & 86 & $\mathrm{~F}$ & $\mathrm{H}$ & $\mathrm{T} 2 \mathrm{~N} 1 \mathrm{M} 0$ & XS & nd & nd \\
\hline 46/Tongue & 58 & M & M & T1N0M0 & nd & nd & nd \\
\hline 47/Tonsil & 59 & M & $\mathrm{P}$ & T3N1M0 & nd & ND & No \\
\hline 48/Pharynx & 59 & M & M & T2N0M0 & nd & nd & nd \\
\hline 50/Larynx & 75 & M & M & T3N0M0 & nd & ND & No \\
\hline 51/Larynx & 48 & M & M & T3N0M0 & nd & ND & No \\
\hline $52 /$ Floor of mouth & 76 & M & $\mathrm{P}$ & T3N1M0 & nd & ND & No \\
\hline $53 /$ Floor of mouth & 81 & M & $\mathrm{H}$ & T1N0M0 & nd & nd & nd \\
\hline 54/Tongue & 45 & $\mathrm{~F}$ & M & T2N0M0 & nd & ND & No \\
\hline 57/Sinus max. & 89 & $\mathrm{~F}$ & $\mathrm{H}$ & T3N0M0 & nd & nd & nd \\
\hline 58/Tongue & 67 & M & M & T1N0M0 & nd & nd & nd \\
\hline 59/Tongue & 67 & M & M & T2NOMO & nd & nd & nd \\
\hline
\end{tabular}

M, male; F, female; H.D., histological differentiation; H, high; M, moderate; P, poor; TNM, (T) tumor; (N), lymph node; (M), metastasis; HS, heavy smoker (>20 cigarettes per day); MS, moderate; smoker (11-20 cigarettes per day); LS, light smoker (1-10 cigarettes per day); NS, non-smoker; XS, ex-smoker; HD, heavy drinker ( $>5$ drinks per day); MD, moderate drinker (3-5 drinks per day); LD, light drinker (1-3 drinks per day); ND, non-drinker and nd, not determined.

and Norway was performed using J-Express Pro software (http://www.molmine.com/software.htm). Chromosomal alterations found in the tumors from the two countries were correlated with clinicopathological data including tumor site, age, gender, histological differentiation, tumor, lymph node, cigarette smoking and use of snuff.

\section{Results}

Clinicopathological evaluation. Samples of HNSCCs from Norway $(n=15)$ and Sudan $(n=11)$ were investigated in this study (Table I). There was a relative predominance of males for the two populations (Norway: 73\%, Sudan: 64\%). Although the tumors were obtained from different sites of the head and neck region in the two populations, the oral cavity was predominant among Sudanese (100\%) compared to Norwegian patients [oral cavity (60\%), larynx (33\%) and maxillary sinus $(7 \%)]$. With regard to histological differentiation of the tumors, high differentiation (HD) was found in four $(36 \%)$ of the Sudanese and five $(33 \%)$ of the Norwegian patients, moderate (MD) in four (36\%) Sudanese and eight (54\%) Norwegian and poor (PD) in three (28\%) Sudanese and two (13\%) Norwegian patients. The tumor stage profile showed advanced stage (III/IV) in six (55\%) of the Sudanese and six (40\%) of the Norwegian samples. For Sudan, the data on the patients' habits of tobacco use/alcohol consumption showed that there were $10(91 \%)$ non-smokers, nine $(82 \%)$ non-drinkers and eight $(73 \%)$ non-users of smokeless tobacco. Among the Norwegian patients, two (13\%) were moderate smokers, six $(40 \%)$ non-drinkers and five (33\%) non-users of smokeless tobacco.

Chromosomal gains common in tumors examined from Sudan and Norway. Array CGH was used to investigate 
Table II. Distribution (\%) of the clinicopathological characteristics of the patients diagnosed with the OSCCs.

\begin{tabular}{|c|c|c|}
\hline Variable & Sudan & Norway \\
\hline Samples, n (\%) & $11(42)$ & $15(58)$ \\
\hline \multicolumn{3}{|l|}{ Gender } \\
\hline Male, n (\%) & $7(64)$ & $11(73)$ \\
\hline Female, n (\%) & $4(36)$ & $4(27)$ \\
\hline Mean age & 62 & 64 \\
\hline \multicolumn{3}{|l|}{ Tumor location } \\
\hline Oral cavity, n (\%) & $11(100)$ & $9(60)$ \\
\hline Larynx, n (\%) & 0 & $5(33)$ \\
\hline Sinus, n (\%) & 0 & $1(7)$ \\
\hline \multicolumn{3}{|l|}{ Tumor differentiation } \\
\hline Poor, n (\%) & $3(28)$ & $2(13)$ \\
\hline Medium, n (\%) & $4(36)$ & $8(54)$ \\
\hline High, n (\%) & $4(36)$ & $5(33)$ \\
\hline \multicolumn{3}{|l|}{ TNM stage } \\
\hline Stage I-II, n (\%) & $5(45)$ & $9(60)$ \\
\hline Stage III-IV, n (\%) & $6(55)$ & $6(40)$ \\
\hline Smoking, n (\%) & $1(10)$ & $3(20)$ \\
\hline Smokeless tobacco use, n (\%) & $3(27)$ & $10(67)$ \\
\hline Alcohol use, n (\%) & $2(18)$ & $9(60)$ \\
\hline
\end{tabular}

genome-wide profiles of chromosomal aberrations in HNSCCs compared to their pair-wise controls. Fig. 1 shows a representative ratio plot for one HNSCC from Norway and one from Sudan. Frequency plots of chromosomal aberrations detected in HNSCCs from Norway and Sudan, are shown in Fig. 2A and B, respectively.

A panel of 41 regions of chromosomal gains common in the samples from the two populations were identified. These regions contained 149 candidate genes. Using KEGG analysis of the 149 genes, we detected candidate genes participating in 13 biological pathways; cell communication, MAPK signaling, calcium signaling, cytokine-cytokine receptor interaction, cell cycle, cell apoptosis, Wnt signaling, focal adhesion, ECMreceptor interaction, cell adhesion molecules, adherens junctions, gap junctions and Jak-STAT signaling. Distribution (\%) of amplifications/deletions and corresponding biological pathways found in the tumors examined from Sudan and Norway are given in Table III. Four pathways were particularly predominant; MAPK signaling, cytokine-cytokine receptor interaction, ECM-receptor interaction and Jak-STAT signaling.

The distribution of common significant gains in the HNSCCs examined from Sudan and Norway is shown in Table IVA. The amplification of MAPK signaling genes (including EGFR, FGF3, FGF4, FGF19, JUND, MYC, $M A P K 12$ and p53) represented one of the largest groups of candidate genes located at different regions of the genome (17/149 genes). We found an increased copy number of several cytokine-cytokine receptor interaction interleukins (IL1O,
IL19, IL20 and IL24) in 6/15 (40\%) of Norwegian and 6/11 (54.5\%) of Sudanese samples mapped to BAC RP11-534L20 (1q32). All genes were previously found to be associated with the development of HNSCCs. The genes involved in cytokine-cytokine receptor interaction were the largest group of genes (23/149) showing chromosomal gains and in addition to the interleukins at $1 \mathrm{q} 32$, there were amplified genes from other regions of the genome, such as CCL26, EGFR, IL17R, IL28A, IL29, IL2RB, IL12RB1, VEGF, XCL2, TNFSF9 and CD4O (Table III and IVA).

Genes participating in cell communication pathways were found to be amplified, including COL1A1, COL4A1, COL11A2, LMNA and NES. Of interest was the observation of COL4A1 copy number increase in 14/15 (93.3\%) of Norwegian and 11/11 (100\%) of Sudanese HNSCC samples (Table IVA). We found a copy number increase of genes involved in the cell cycle regulatory pathway $p 21, p 19^{\text {INK4d, }}$, EP300, CCND1, CCND2 and p53 (Table IVA). Gains were also observed at the chromosomal region containing CDK10 in $3 / 15(20 \%)$ of Norwegian and $4 / 11(36.4 \%)$ of Sudanese samples. The amplification of chromosomal regions containing regulatory genes of apoptosis were found in samples from the two populations, particularly $B A D, B C L 2 L 1$ and $F A D D$. An increased copy number on $\log _{2}>2$ was observed in two samples from Norway $(\mathrm{N} 17, \mathrm{~N} 46)$ and a copy number on $\log _{2}$ $>3$ was found in two samples from Norway (N48, N50) and one sample from Sudan (S50) of regions harboring the genes NTRK1, BIRC2 and BIRC3 were observed. A summary of the common copy number gains in Norway and Sudan are shown in Fig. 3A and B.

We found several altered regions on chromosome 1 in the two populations, with a copy number increase of $1 \mathrm{p} 36,1 \mathrm{q} 21$, 1q23 and 1q32. The TNFRSF4 gene, mapped to BAC CTB$14 \mathrm{E} 10$ at $1 \mathrm{p} 36$, was amplified in $5 / 15(33.3 \%)$ and $3 / 11$ $(27.3 \%)$ of Norwegian and Sudanese patients, respectively. One of the Norwegian samples (N21) showed a copy number increase higher than two of TNFRSF4 on the $\log _{2}$ scale. In the two populations, BAC RP1-148L21 at 1q21 showed a notable amplification of members of the S100A gene family. An increased copy number of a regulatory gene of the cell cycle, Mdmx and KISS-1 precursor was detected in $26.7 \%$ of the Norwegian and $27.3 \%$ of the Sudanese HNSCC samples. It was noteworthy to observe that the gene for metastasis suppressor protein 1 (MTSS1), mapped to BAC RP11-532M24 at 8 p22, was amplified in $6 / 15(40 \%)$ of the Norwegian and $8 / 11(72.7 \%)$ of the Sudanese HNSCC samples and one Sudanese patient (S69) showed a copy number increase higher than three of this region on the $\log _{2}$ scale.

Co-amplification was detected at 11q13, hosting EMS1, SHANK2 and CCND1 genes. BAC RP11-750P5 at 11q22 contained several matrix metallopeptidases (MMPs) cell-cell interaction genes, including $M M P 1, M M P 3, M M P 7, M M P 8$, MMP10, MMP12, MMP13 and MMP20, which were coamplified in the two populations.

Chromosomal losses common in tumors examined from Sudan and Norway. We identified 28 candidate genes that were located in deleted regions in the two populations. The distribution of common significant losses in the tumors examined from Norway and Sudan is shown in Table IVB. 
A

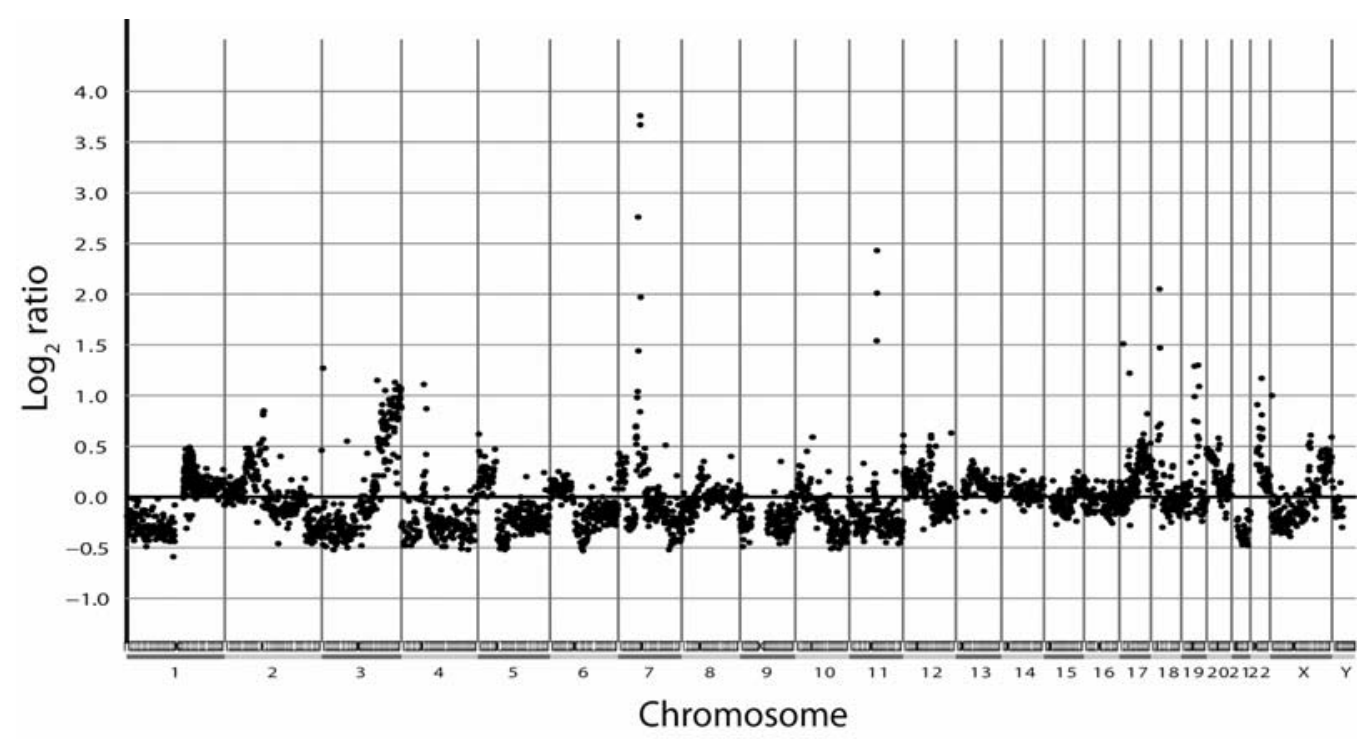

B

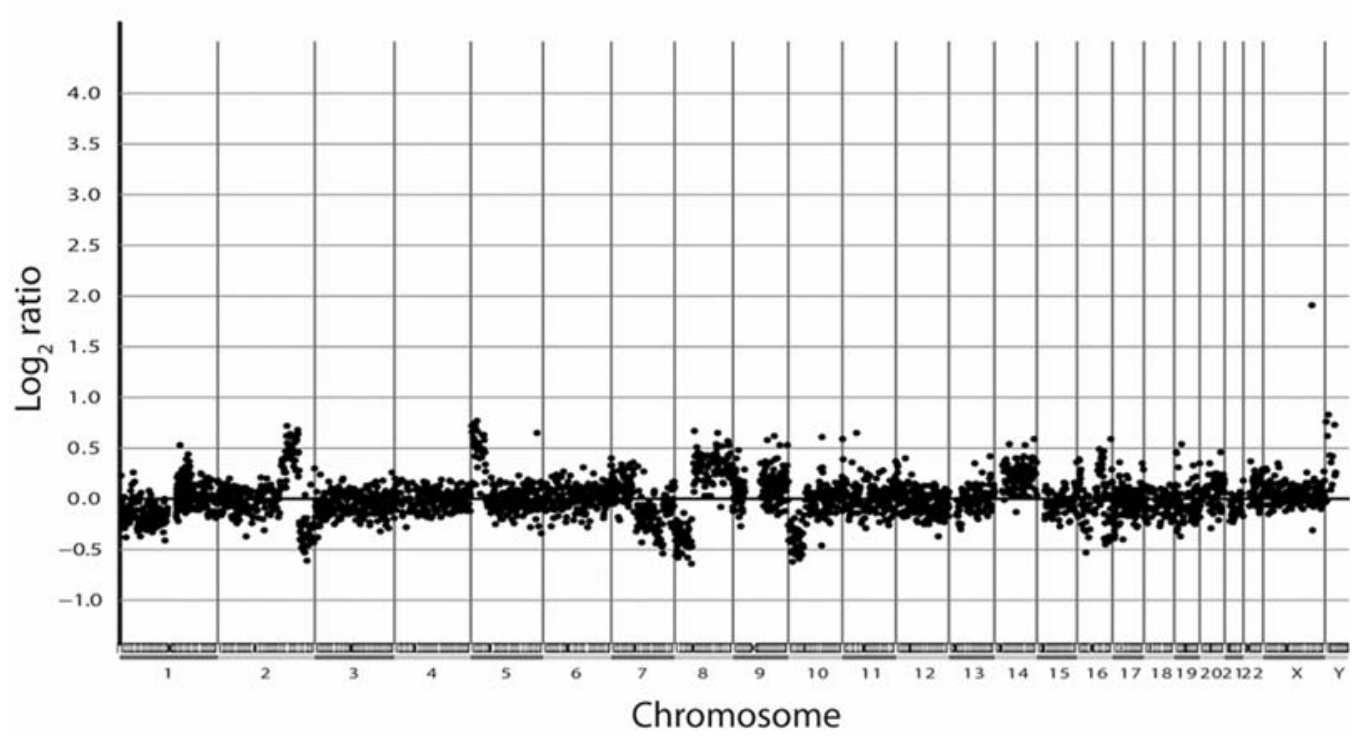

Figure 1. Chromosomal alterations in a case of oral squamous cell carcinoma from Norway (A, case N50) and Sudan (B, case S65).

The deletion of chromosomal regions hosting genes involved in MAPK signaling included $F G F 5, F G F 9$ and $R A F 1$ (involved in the Ras-dependant signaling pathway between the receptors and the nucleus), as well as TGFBR2. Common copy number losses in the samples from Norway and Sudan are shown in Fig. 3C. We found three genes participating in cytokine-cytokine receptor interaction were deleted, IL5RA, TGFBR2 and TNFSF11 (mapped to BAC RP11-10H6, RP1169K20 and RP11-117I13, respectively). For the two countries, a copy number loss at 3 p22 was observed in $5 / 15$ $(33.3 \%)$ of Norwegian and $3 / 11(27.3 \%)$ of Sudanese HNSCCs. This region contains a gene involved in DNA repair, MHL1 (DNA mismatch repair protein). The cell cycle genes $p 15^{I N K 4 a}$ and $p 16^{I N K 4 b}$ mapped to BAC RP11-149I2 at 9p21, which was deleted in 4/15 (26.7\%) and 3/11 (27.3\%) of Norwegian and Sudanese patients, respectively.
Among the genes located in common deleted chromosomal regions, MAPK signaling, cytokine-cytokine receptor interaction and the regulation of the actin cytoskeleton represented the predominant biological pathways.

Hierarchical clustering. Hierarchical clustering of the chromosomal gains and losses found in the tumors examined from patients from Sudan and Norway and the clinicopathological data were performed (Fig. 4). Although, there was a tendency for the majority of the tumors from each country to group tightly to each other in one of the two main subgroups, we did not find any specific correlation between chromosomal alterations and clinicopathological parameters such as age, gender, tumor stage, tumor site, differentiation status or social habits of alcohol, tobacco and snuff use. 

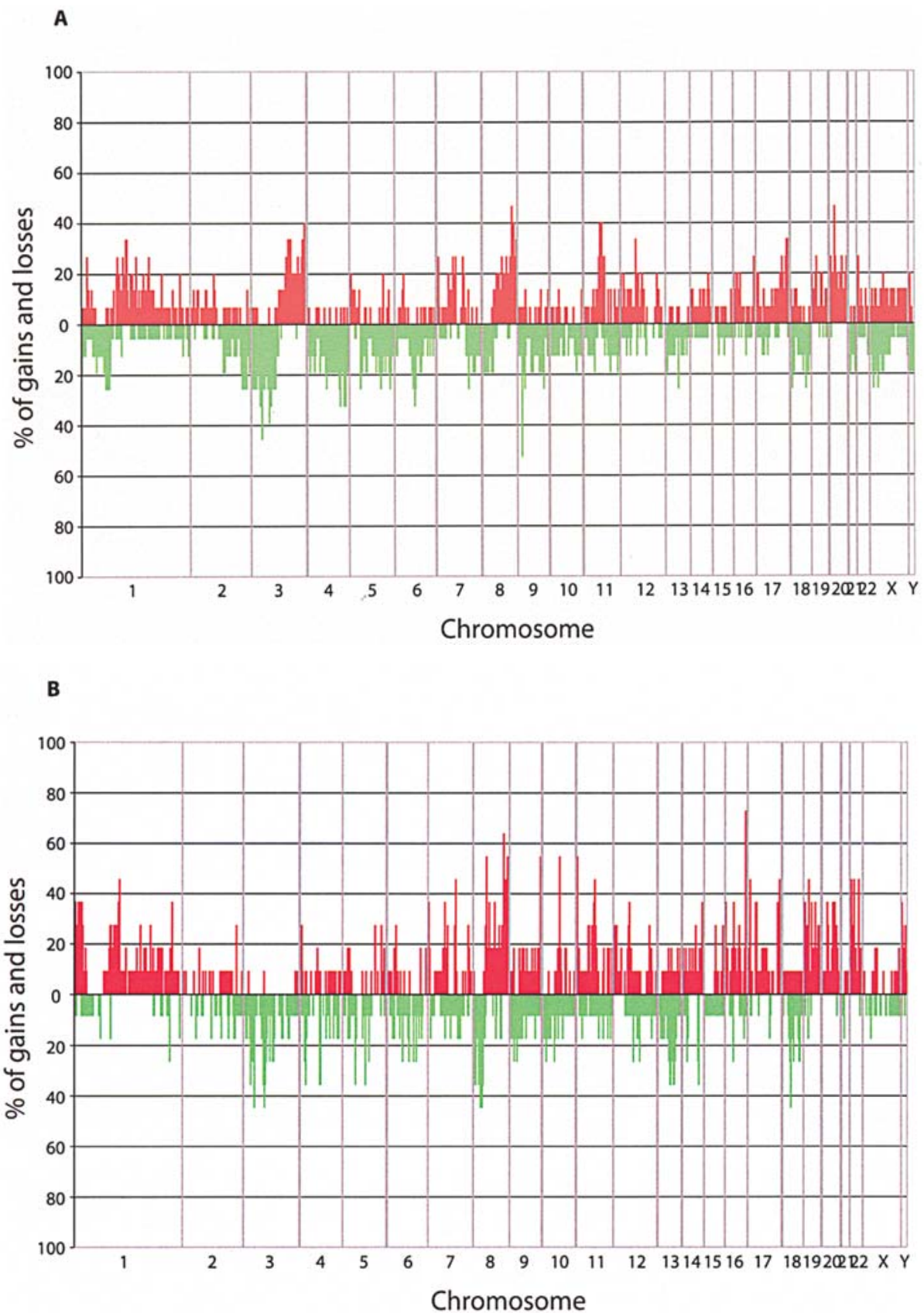

Figure 2. Genomic frequency plot representing amplified and deleted chromosomes in oral squamous cell carcinomas from Norway (A) and Sudan (B).

Chromosomal gains and losses that differ significantly between populations. Furthermore, we analyzed the data in search for regions of copy number gains/losses specific for each population. The results of country-specific chromosomal alterations in the HNSCCs examined from Sudan and Norway are shown in Fig. 2A and B. For Sudan, we found regions hosting 75 genes to be preferentially amplified. The genes included COL5A1, COL2A1, RASEF, MAPK4 and a large family of keratins (KRT10, KRT12, KRT20, KRT23, $K R T 24$ and $K R T 25 A-D)$. Additionally, we found chromosomal regions that were deleted only in Sudanese samples. These regions hosted 66 genes, among others several interleukins (IL22RA1, IL28RA1, IL7R, BIRC6, COL1A2, MMP19 and $C D K 2)$. For Norway, we detected preferentially amplified regions with 33 genes, of which five $(15 \%)$ participated in the
MAPK signaling pathway, four (12\%) in the regulation of actin cytoskeleton and four (12\%) as cell adhesion molecules (CAMs). Deletions of chromosomal regions specific for Norway affected 65 genes, including several interleukins (IL3,IL4,IL5, IL9 and IL13) and CD2, CD58, COL7A1, $M A P K 10$ and $C D 44$. Collagens, keratins and interleukins were the predominant genes found to be located in amplified or deleted regions in each population separately.

\section{Discussion}

Genome-wide analysis by array CGH was used to identify quantitative chromosomal alterations in HNSCCs from Sudan and Norway. The amplification and deletion of regions harboring in total 149 and 28 candidate genes, respectively, 
A Common copy number gains: Norway and Sudan

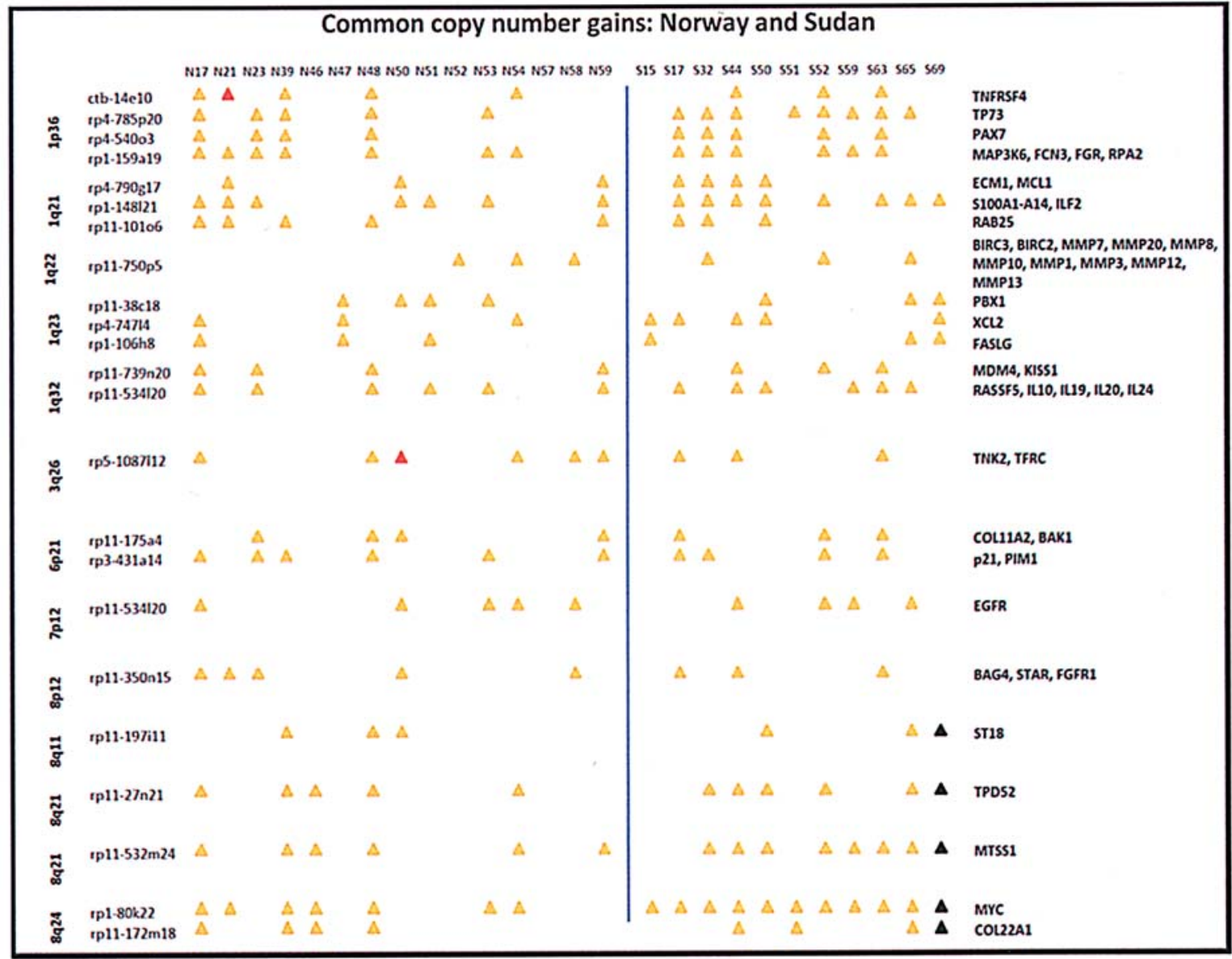

B Common copy number gains: Norway and Sudan cont.

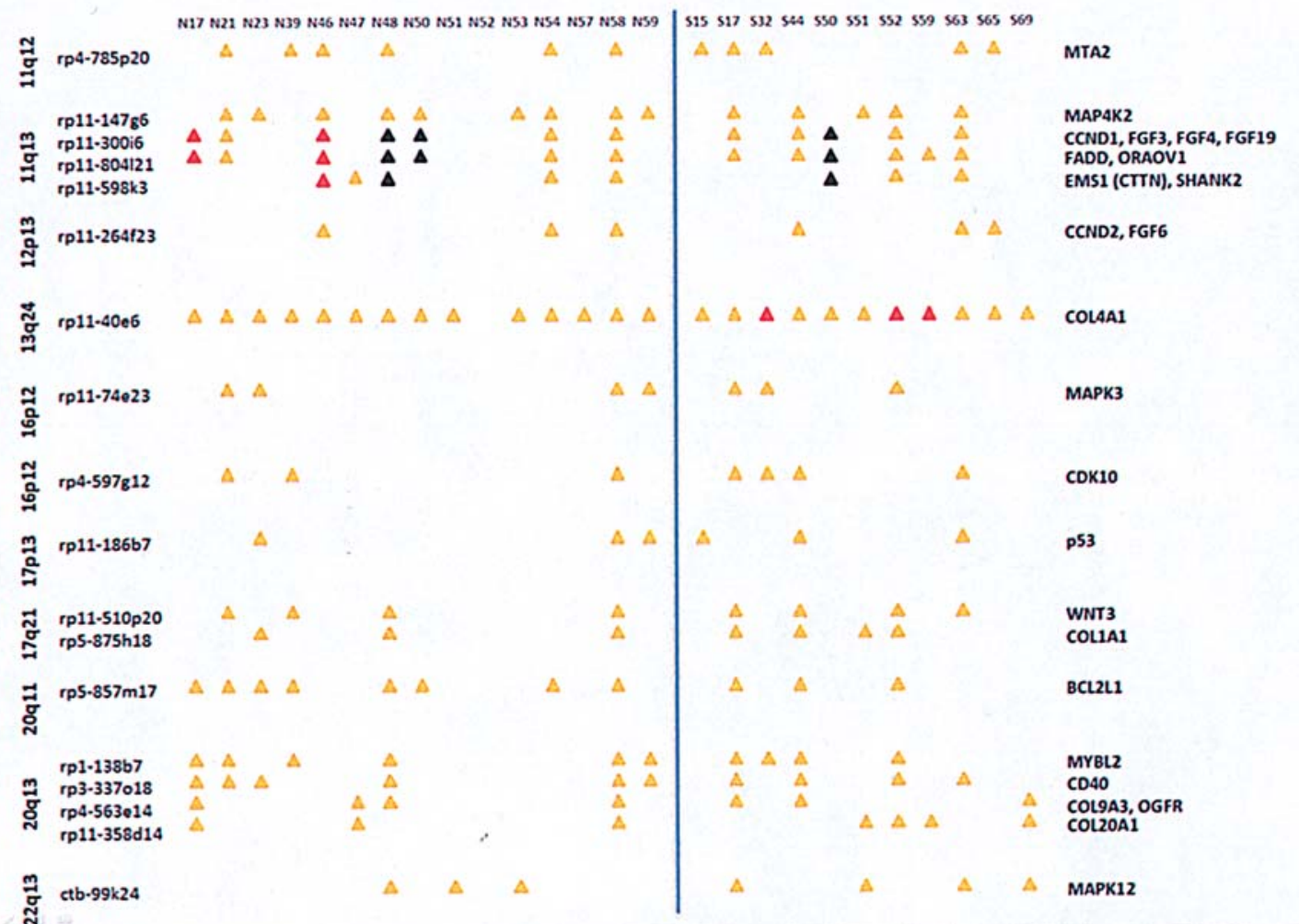


C

\begin{tabular}{|c|c|c|c|c|c|c|c|c|c|c|c|c|c|c|c|}
\hline \multicolumn{16}{|c|}{ Common copy number losses: Norway and Sudan } \\
\hline & & mar & N21 naz & son & Na6 Na & nas ns & so nst nsz & 3 NS4 NST & nsa ns? & |sis siz & s32 s & 44 sso & $1 \mathrm{ss2}$ & 563 s65 so & \\
\hline$\underset{\mathrm{\sigma}}{\tilde{m}}$ & ${ }_{\mathrm{rp} 11-483 \mathrm{~m} 6}^{\mathrm{rp} 11-163 \mathrm{~d} 23}$ & $\nabla$ & & & $\nabla \nabla$ & $\nabla \nabla$ & $\nabla \nabla \nabla$ & & $\nabla$ & $\nabla$ & $\nabla$ & $\nabla$ & & $\nabla y$ & $\begin{array}{l}\text { RAF1, TIMP4 } \\
\text { WNI7A }\end{array}$ \\
\hline 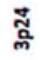 & $r p 11-69 k 20$ & $\nabla$ & $\nabla$ & $\nabla$ & $\nabla$ & $\nabla v$ & $\nabla$ & & $\nabla$ & & $\nabla$ & $\nabla$ & $\nabla$ & & TGFBR2 \\
\hline ฐ్ల & $\mathrm{rp} 11-134 \mathrm{c} 18$ & $\nabla$ & $\nabla$ & & & $\nabla v$ & $\nabla$ & & $\nabla$ & $\nabla$ & $\nabla$ & $\nabla$ & & & МเH1 \\
\hline$\frac{a}{a}$ & 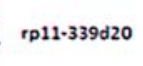 & & & $\nabla$ & & $v$ & $\nabla$ & & $\nabla \nabla$ & $\nabla$ & $\nabla$ & $\nabla$ & & $\nabla$ & surz \\
\hline$\frac{n}{a}$ & $r p 11 \cdot 258 n 2$ & & & & & $v$ & $\nabla$ & & $\nabla \nabla$ & $\nabla$ & & $\nabla$ & $\nabla$ & $\nabla$ & FGFS \\
\hline జ్ & $\begin{array}{l}r p 11 \cdot 17114 \\
c t c-329 h 14\end{array}$ & & $\nabla$ & $\nabla$ & $\nabla$ & & $\nabla$ & $\nabla$ & $\nabla$ & $\nabla$ & & v & $\nabla$ & $\nabla \nabla$ & $\begin{array}{l}\text { EFNAS } \\
\text { FER }\end{array}$ \\
\hline 总 & $\mathrm{ctc}-320 \mathrm{c} 6$ & & $\nabla$ & $\nabla$ & & & & & $\nabla$ & $\nabla$ & & $\nabla$ & $\nabla$ & & CCNG1 \\
\hline ลू & $\mathrm{rp} 11-149 \mathrm{i2}$ & $\nabla$ & & & $\nabla$ & v & v & & $\nabla$ & $v$ & & $\nabla$ & $\nabla$ & & p16, p15 \\
\hline సี & $r p 11-541116$ & $\nabla$ & & & $\nabla$ & $\nabla$ & $\nabla$ & & & $\nabla$ & & $\nabla$ & & $v$ & RASEF \\
\hline$\underset{\mathbb{J}}{\mathbb{Z}}$ & $\mathrm{rp} 11-264020$ & & & & & $\nabla \nabla$ & $\nabla \nabla$ & & & & & $\nabla$ & & $v$ & fu1 \\
\hline 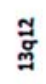 & $\mathrm{rp} 11-110 \mathrm{k}$ & & & & $\nabla$ & & $\nabla$ & & $\nabla$ & & $v$ & $\nabla$ & & $\nabla$ & FGF9 \\
\hline$\underset{\tilde{g}}{\ddot{\Xi}}$ & $r p 11-117 i 13$ & & $\nabla$ & & $\nabla$ & & $\nabla$ & & & & $v$ & $\nabla$ & & v & TNFSF11 \\
\hline
\end{tabular}

Figure 3. Common copy number alterations in HNSCC samples from Norway and Sudan; (A and B) gains and (C) losses. Triangles: yellow, 1-fold copy number increase; red, 2-fold copy number increases; black, 3-fold copy number increases and green, 1-fold copy number decrease.

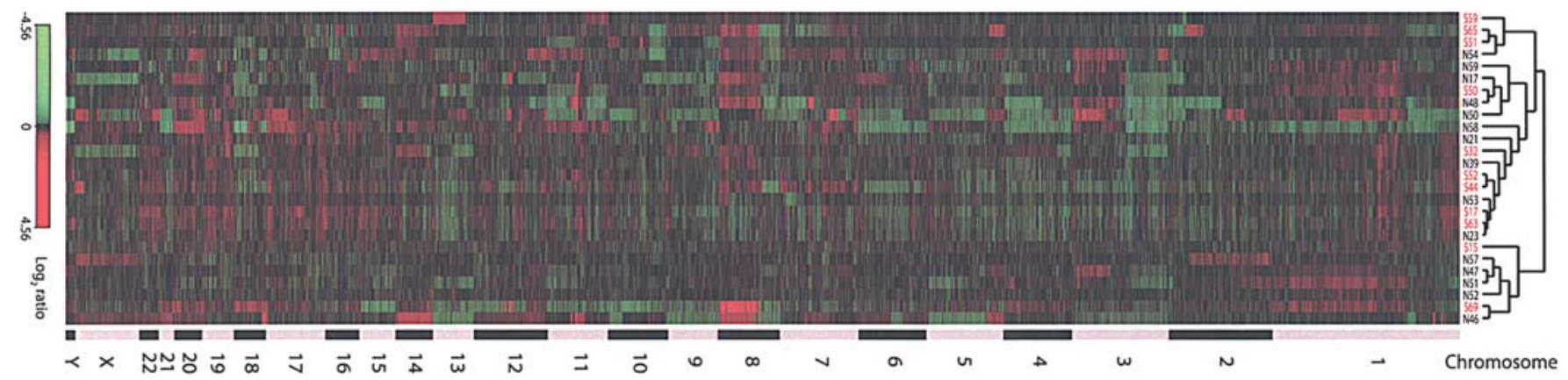

Figure 4. Hierarchical clustering of the chromosomal gains and losses found in the tumors examined from patients from Sudan (red numerals) and Norway (black numerals).

were found as common for the samples examined from the two countries. Although the degree of copy number increase/decrease varied by \pm 3 -4-fold on the $\log _{2}$ scale between the two populations, the alterations seemed to affect the same chromosomal regions. Affected genes were involved in cell communication, MAPK signaling, cell cycle, apoptosis, Jak-STAT signaling, as well as DNA repair.

Of interest was the detection of amplification of 13q24 in $100 \%$ of the Sudanese and $93.3 \%$ of the Norwegian samples. This region contains the gene COL4A1, which is a basic structural component of all basement membranes and has previously been reported in the HNSCCs (20-23). The resulting amplification of this gene may be one of the important factors contributing to structural disintegration of the basement membrane in cells undergoing a dysplastic formation.

Several previous studies have shown overexpression or mutation of the EGFR gene in a significant number of cancers, including different subtypes of HNSCCs. The $7 \mathrm{p} 12$ region containing this gene was found amplified in 36.3 and $33.3 \%$ of Sudanese and Norwegian samples, respectively. Overexpression of EGFR and MYC (found to be amplified in 100\% 
Table III. Distribution (\%) of the chromosomal amplifications/deletions and the corresponding biological pathways.

\begin{tabular}{|c|c|c|c|}
\hline Pathway groups & Amplifications & Deletions & Total no $(\%)$ with alterations \\
\hline \multicolumn{4}{|c|}{ Cell communication } \\
\hline Sudan & $4(4 \%)$ & $6(10 \%)$ & $10(14 \%)$ \\
\hline Norway & 0 & $1(2 \%)$ & $1(2 \%)$ \\
\hline Total & $4(3 \%)$ & 0 & $4(3 \%)$ \\
\hline \multicolumn{4}{|l|}{ MAPK signaling } \\
\hline Sudan & $6(6 \%)$ & 0 & $6(6 \%)$ \\
\hline Norway & $5(15 \%)$ & $6(9 \%)$ & $11(24 \%)$ \\
\hline Total & $17(11 \%)$ & $4(14 \%)$ & $21(25 \%)$ \\
\hline \multicolumn{4}{|c|}{$\begin{array}{l}\text { Calcium signaling, cytokine-cytokine } \\
\text { receptor interaction }\end{array}$} \\
\hline Sudan & $9(9 \%)$ & $6(10 \%)$ & $15(19 \%)$ \\
\hline Norway & $3(10 \%)$ & $10(15 \%)$ & $13(25 \%)$ \\
\hline Total & $24(16 \%)$ & $3(11 \%)$ & $27(27 \%)$ \\
\hline \multicolumn{4}{|l|}{ Cell cycle } \\
\hline Sudan & $2(2 \%)$ & $3(5 \%)$ & $5(7 \%)$ \\
\hline Norway & $2(6 \%)$ & $3(4 \%)$ & $5(10 \%)$ \\
\hline Total & $8(5 \%)$ & 0 & $8(5 \%)$ \\
\hline \multicolumn{4}{|l|}{ Wnt signaling } \\
\hline Sudan & $3(3 \%)$ & 0 & $3(3 \%)$ \\
\hline Norway & 0 & $3(4 \%)$ & $3(4 \%)$ \\
\hline Total & $7(5 \%)$ & $3(11 \%)$ & $10(16 \%)$ \\
\hline \multicolumn{4}{|c|}{$\begin{array}{l}\text { Focal adhesion, ECM-receptor } \\
\text { interaction, cell adhesion }\end{array}$} \\
\hline Sudan & $6(6 \%)$ & $8(12 \%)$ & $14(18 \%)$ \\
\hline Norway & $7(21 \%)$ & $10(15 \%)$ & $17(36 \%)$ \\
\hline Total & $22(15 \%)$ & $2(7 \%)$ & $24(22 \%)$ \\
\hline \multicolumn{4}{|c|}{$\begin{array}{l}\text { Gap junction, tight junctions, } \\
\text { adherens-junction }\end{array}$} \\
\hline Sudan & $7(7 \%)$ & $2(3 \%)$ & $9(10 \%)$ \\
\hline Norway & $1(3 \%)$ & $3(4 \%)$ & $4(7 \%)$ \\
\hline Total & $5(3 \%)$ & $3(11 \%)$ & $8(14 \%)$ \\
\hline \multicolumn{4}{|c|}{ Jak-STAT signaling } \\
\hline Sudan & $2(2 \%)$ & $3(5 \%)$ & $5(7 \%)$ \\
\hline Norway & $2(6 \%)$ & $9(13 \%)$ & $11(19 \%)$ \\
\hline Total & $17(11 \%)$ & $1(4 \%)$ & $18(15 \%)$ \\
\hline \multicolumn{4}{|c|}{ Regulation of actin cytoskeleton } \\
\hline Sudan & $2(2 \%)$ & $3(5 \%)$ & $5(7 \%)$ \\
\hline Norway & $4(12 \%)$ & $5(7 \%)$ & $9(19 \%)$ \\
\hline Total & $9(6 \%)$ & $3(11 \%)$ & $12(17 \%)$ \\
\hline
\end{tabular}

of the Sudanese and $46.7 \%$ of the Norwegian samples in our experiment), represent common genetic alterations in oralesophageal cancers $(24,25)$. The genes regulate multiple biological processes, including cell proliferation, differentiation and growth. The cell cycle gene $p 15^{I N K 4 a}$, which interacts with $C D K 4 / C D K 6$ and negatively regulates the proliferation of normal cells and $p 16^{I N K 4 b}$, which potentially affects TGF- $\beta$ induced cell cycle arrest and inhibits $C D K 4$ and $C D K 6$, both mapped to BAC RP11-149I2 at 9p21, which was found deleted in nearly $27 \%$ of the samples from the two populations.

Of interest was the finding of the copy number increase of 1q32 harboring the MDM4 gene, which plays a key role as a 


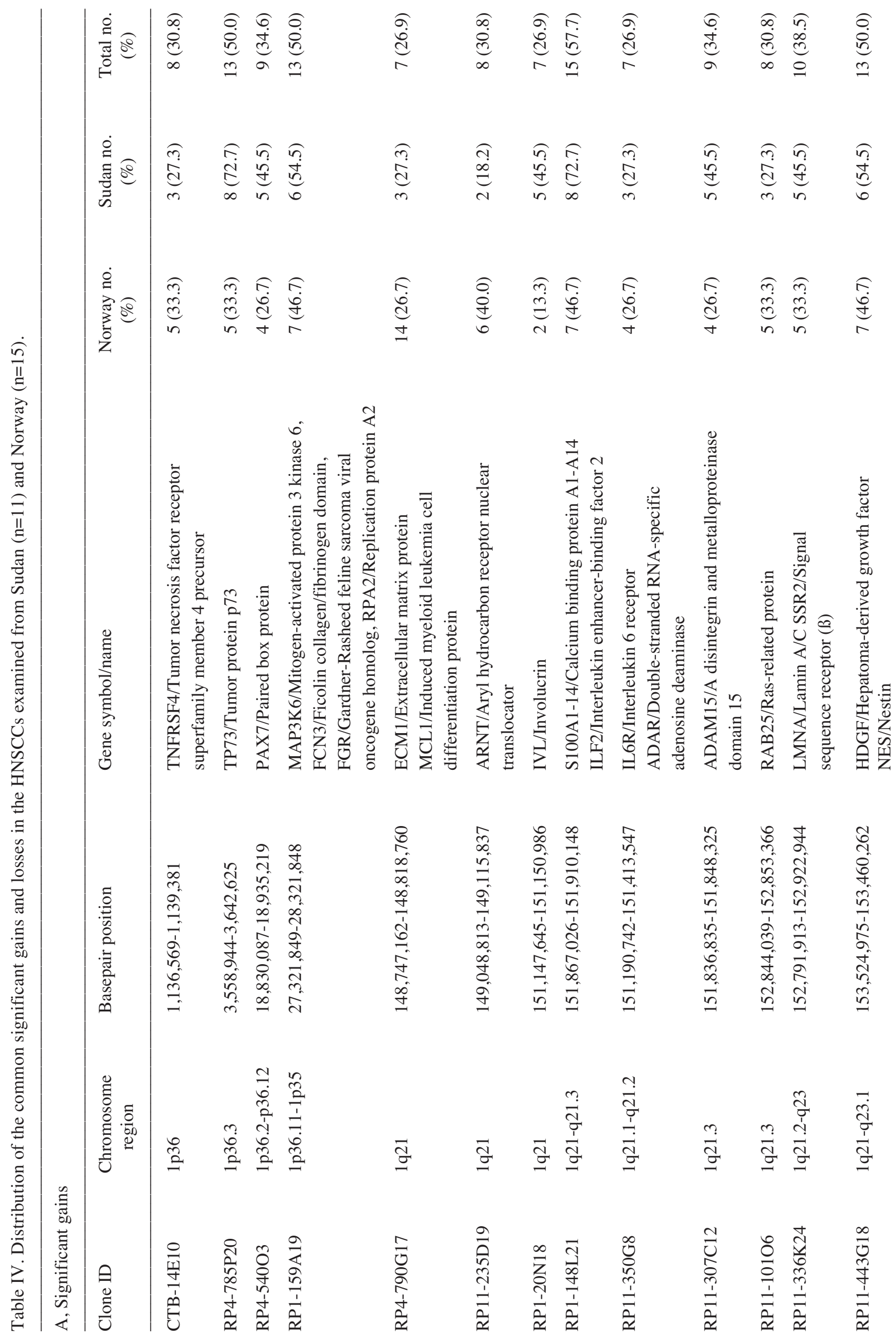




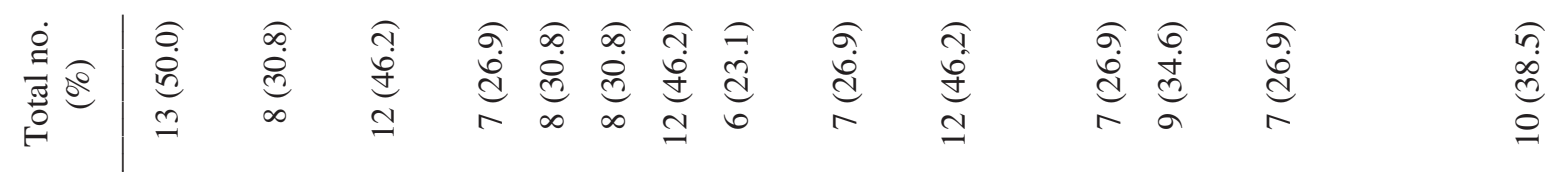

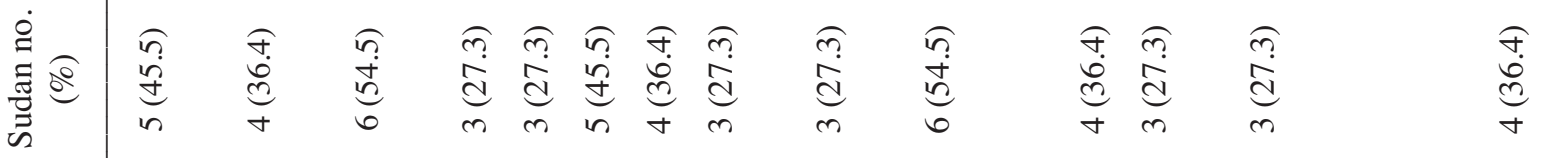

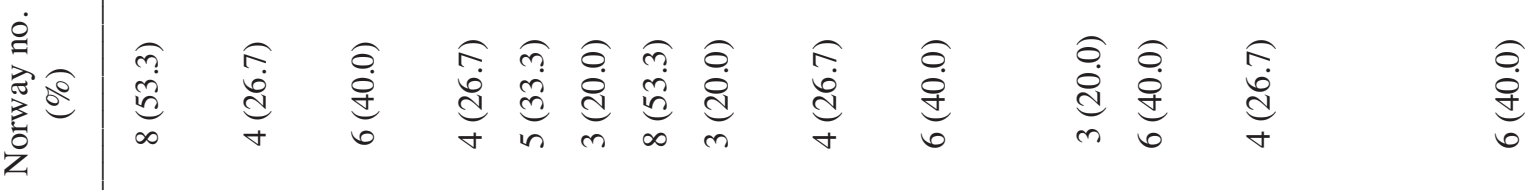

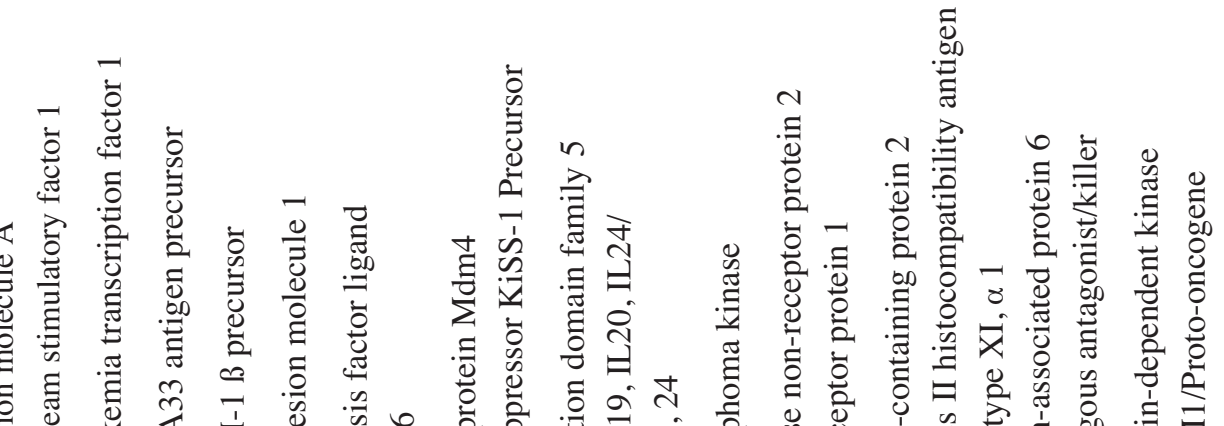

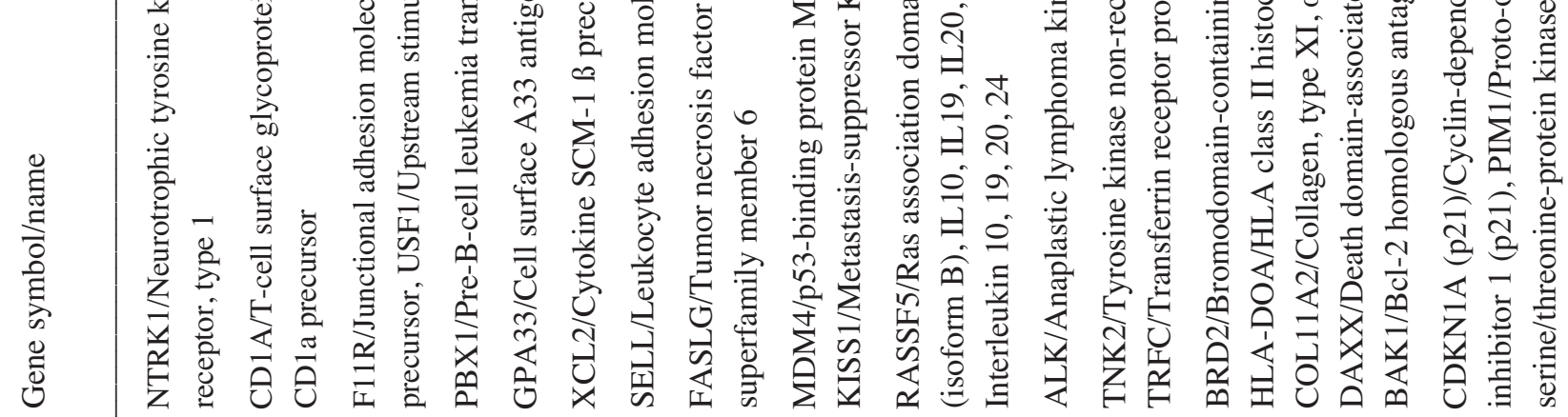

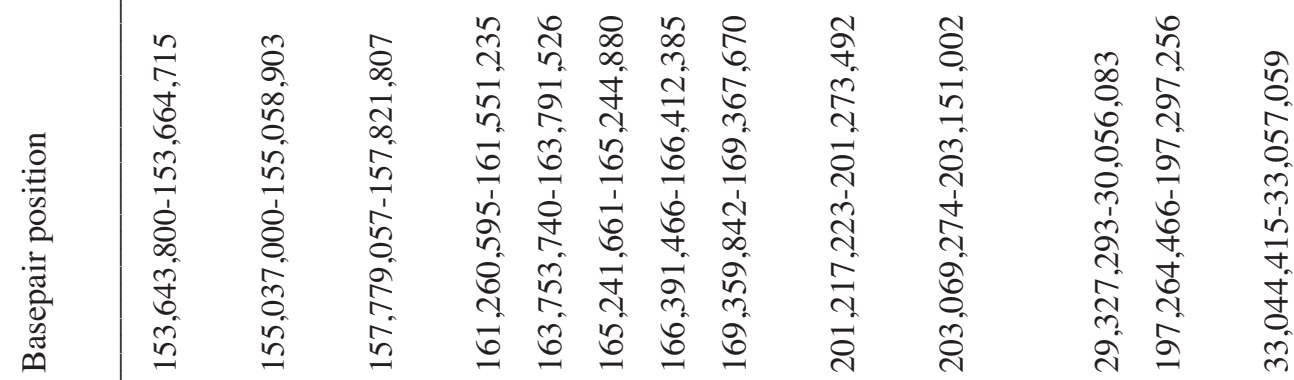

0
0
0
0
0
0
0
0
0
0
0
0
0
0

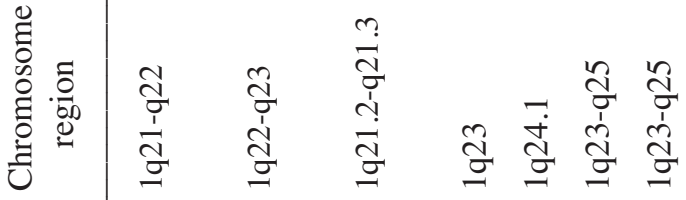

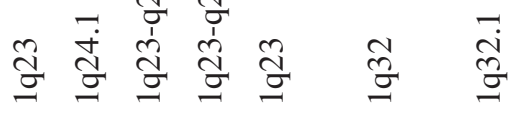

तิ ڤัँ है

$\frac{\text { กุ }}{\text { है }}$

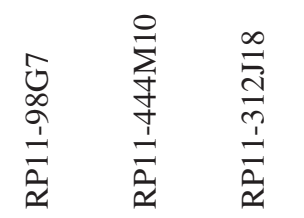

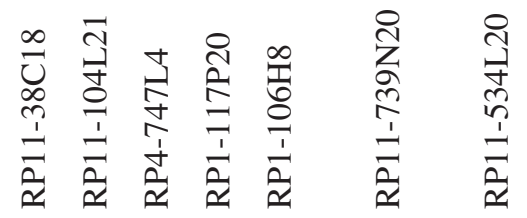

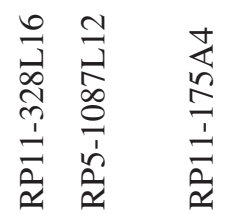

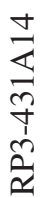




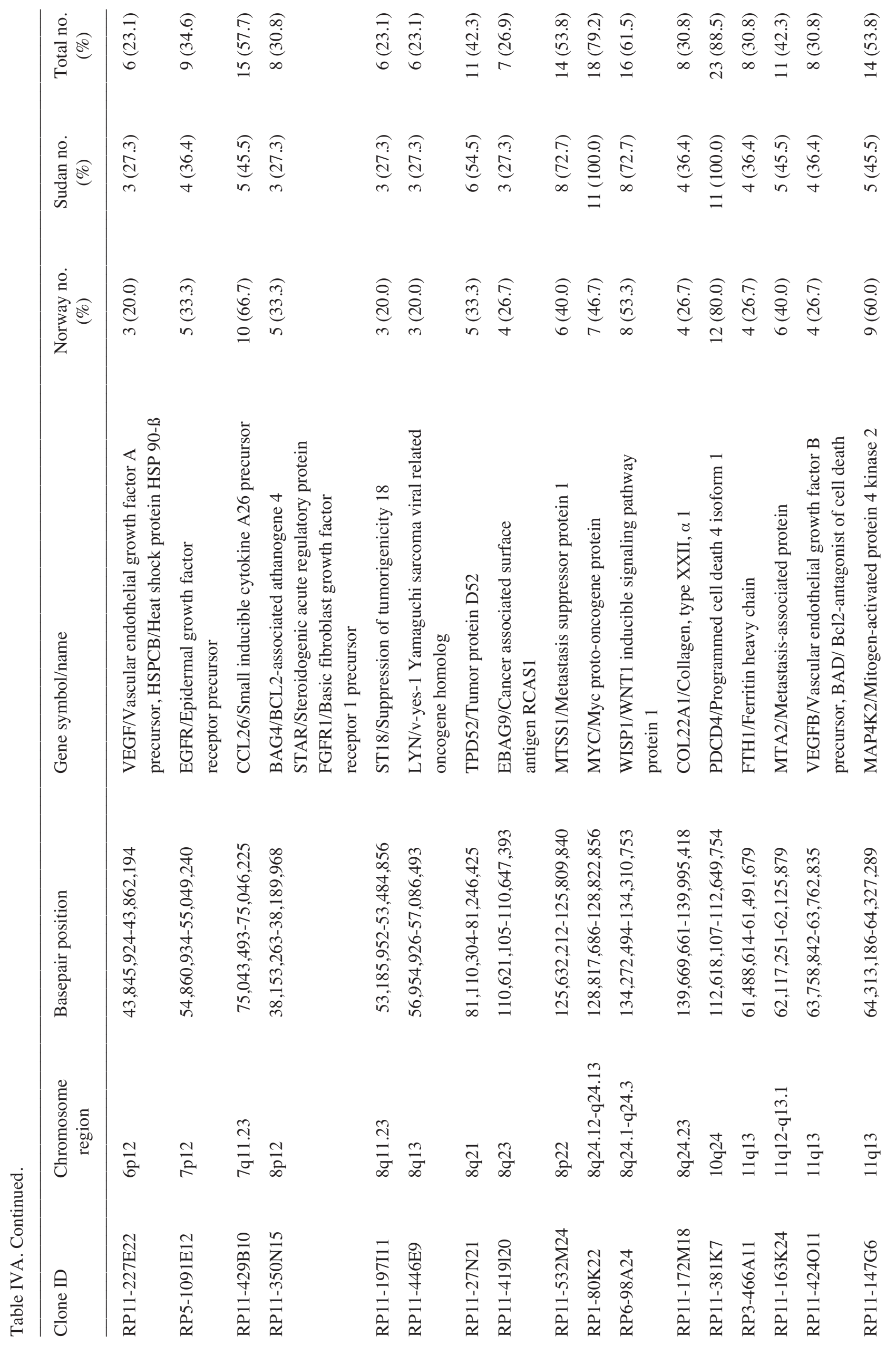




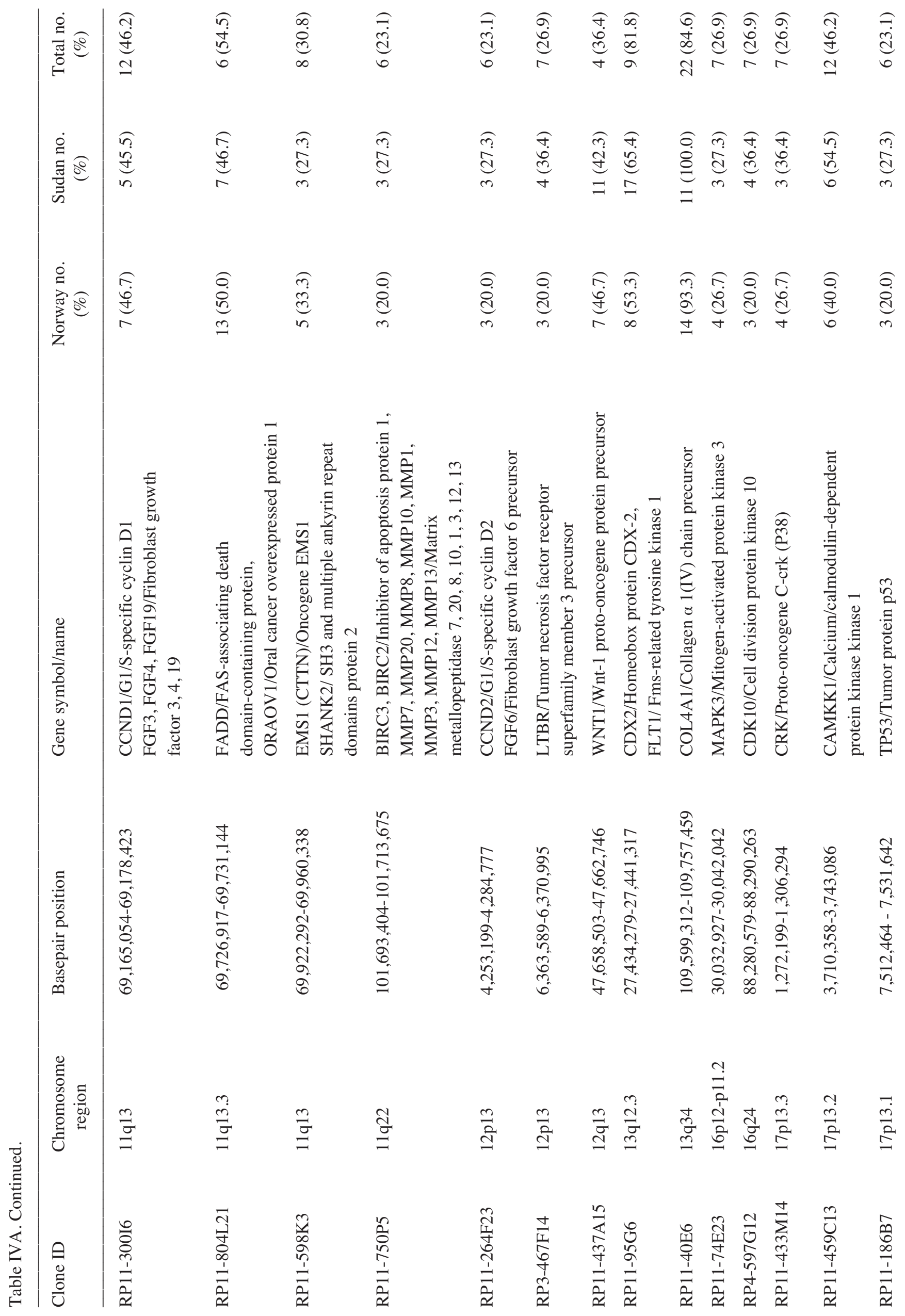




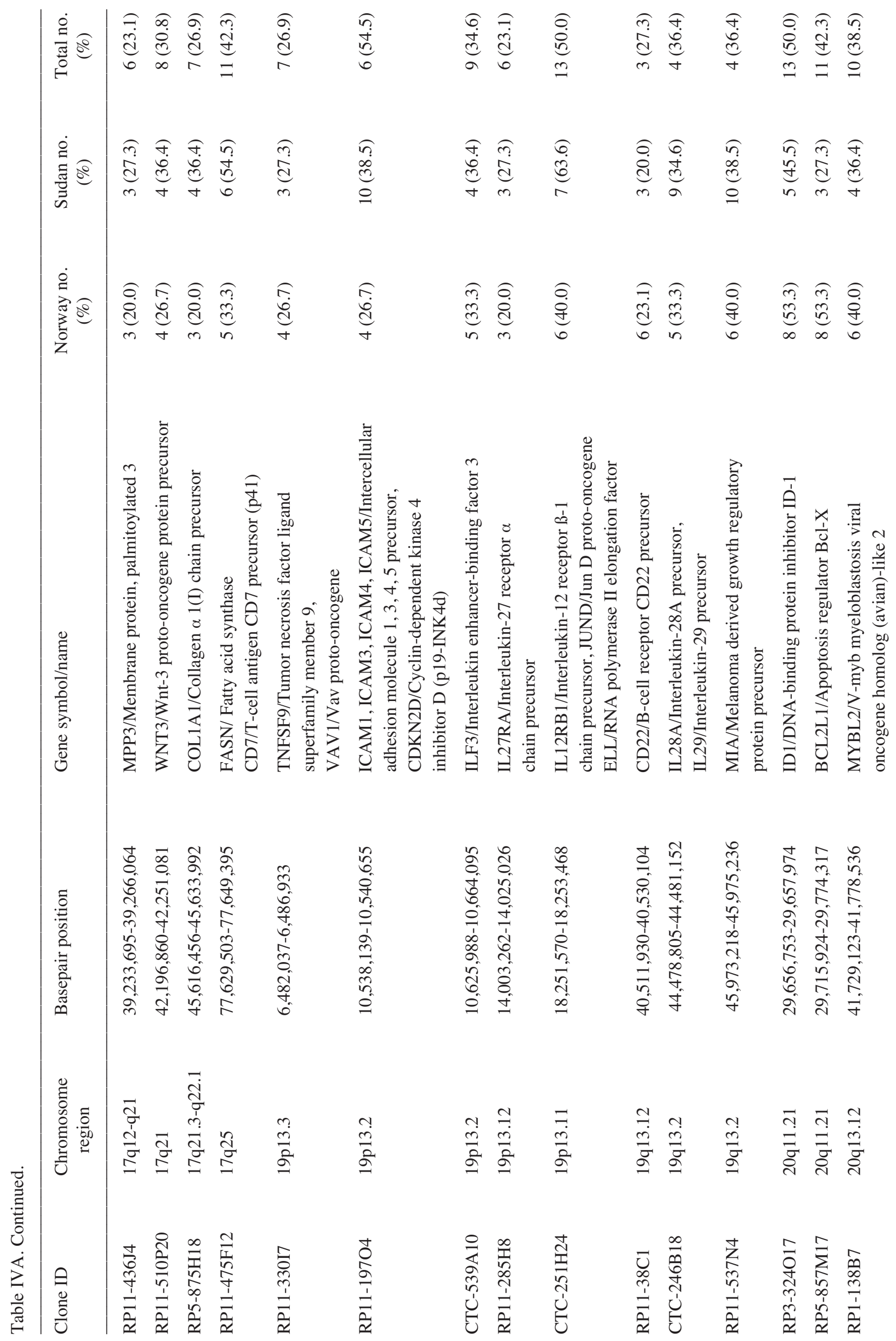




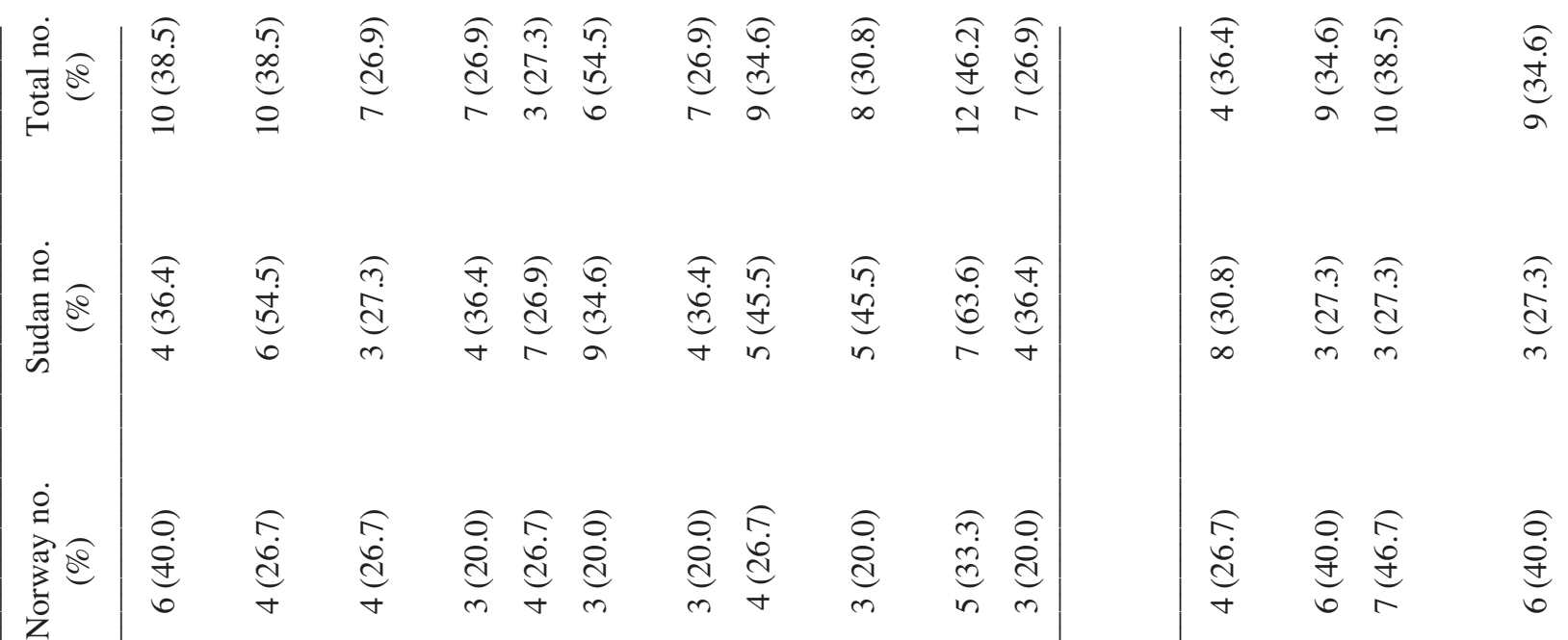

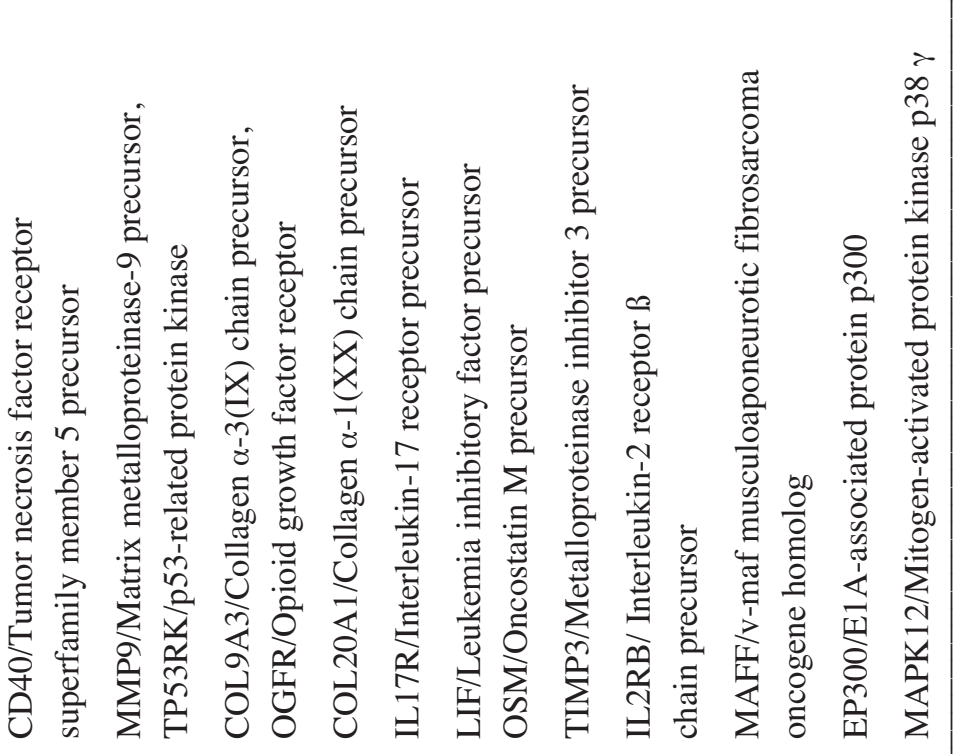

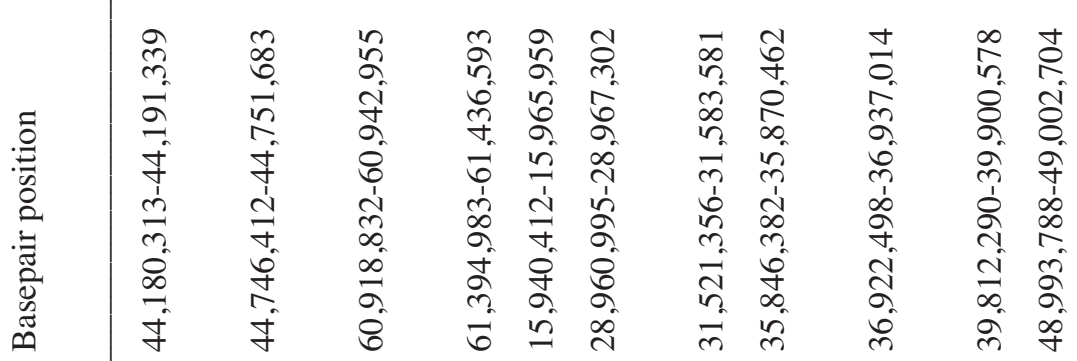

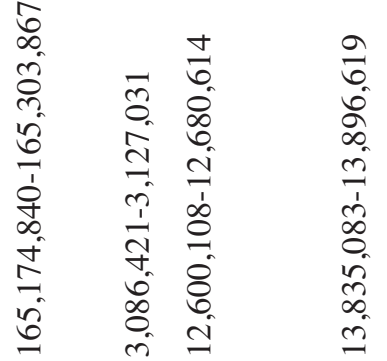

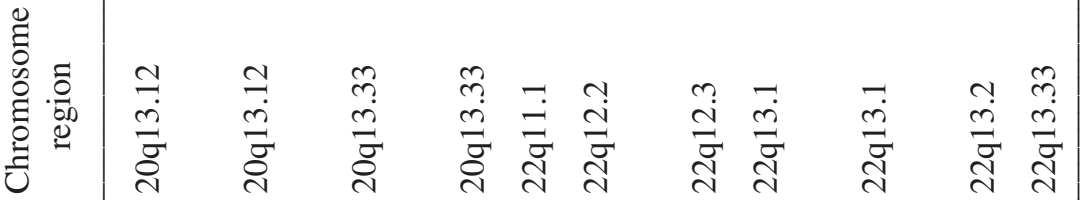

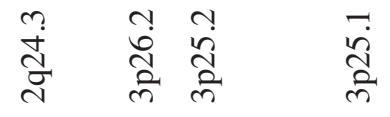




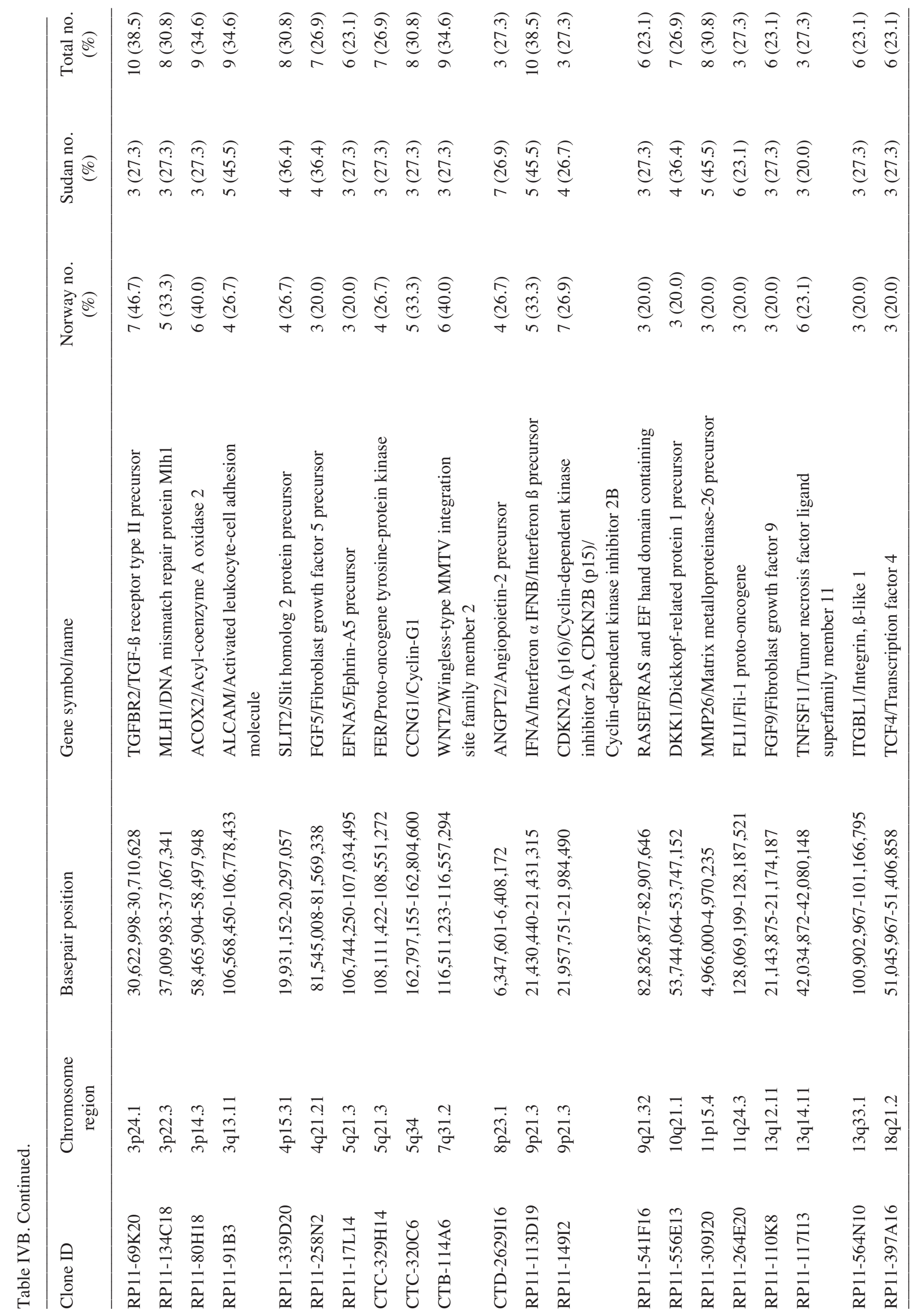


negative regulator of $p 53$ (43). Although a number of various human cancers show amplification and overexpression of $M D M 4$, the exact mechanism of the negative regulation of $p 53$ by the mdm 4 protein and the contribution of this to tumor formation, remains uncertain (44). We found a predominant copy number increase of the chromosomal region hosting $p 53$, which has been previously reported as mutated and overexpressed in HNSCCs examined from Sudan and Norway $(18,19)$.

We detected the amplification of $1 \mathrm{q} 21$, harboring the calcium-binding protein genes S100A1-A14, in $72 \%$ of Sudanese and $46 \%$ of Norwegian samples. These findings are in agreement with previous studies showing potential involvement of the S100A gene family in OSCCs examined from Sudan and Norway $(31,32)$. An interaction between $S 100 A 1$ and $-A 4$ has previously been studied with the suggestion that they may be involved in cancer invasion and metastasis $(33,34)$. The $S 100 A 2$ gene, has previously been reported as a potential marker in early-stage patients with oral cancer and was shown to interact with $p 53$, thereby modulating its activity $(35,36)$.

Loss of heterozygosity ( $\mathrm{LOH}$ ) and frequent chromosomal rearrangements at $11 \mathrm{q}$ in HNSCC have been previously described $(37,38)$. Of interest, is the finding that the amplification of $11 \mathrm{q} 13$, containing among others CCND1, registered on average in $30.3 \%$ of all samples. This chromosomal region was found to be of key importance in the early events of tumor development and progression by protooncogene activation, and was recently reported to be gained in another array CGH study of HNSCCs (26). Amplification of CCND1 has been reported in bladder, gastric, breast and pancreatic cancers, suggesting its role as a predictive biomarker (27-30).

In head and neck cancers, high-level amplification and/or overexpression of $C C N D 1$ has been suggested to enhance tumor growth, aggressive development and poor patient prognosis $(13,39,40)$. The $11 \mathrm{q} 13$ amplicon hosts in addition to CCND1, EMS1 and SHANK2 two important growth factors, $F G F 3$ and FGF4. These genes seem to play an important role in driving the 11q13 amplification and show good correlation between the amplification status and overexpression (41).

Amplification of $11 q 22$ were found in $27 \%$ of the Sudanese and $20 \%$ of the Norwegian samples and this finding seems to be consistent with previous reports in a genome-wide analysis of HNSCCs by array CGH (42). The region hosts two genes that function as inhibitors of apoptosis, BIRC2 and BIRC3, as well as eight members of a rich family of matrix metallopeptidases (MMPs) that play an important role in cell-cell interaction, remodeling and degradation of extra-cellular matrix (MMP1, MMP3, MMP7, MMP8, MMP10, MMP12, $M M P 13$ and $M M P 20)$. Previous studies have shown that protelytic/enzymatic properties of $M M P s$ are essential for a tumor's ability to initiate the degradation of ECM and to access and establish new blood and lymphatic pathways in order to invade new regions and metastasize to remote organs (45). The status of the copy number increase of the MMPs found in our study, along with amplification of chromosomal regions hosting genes involved in cell apoptosis, such as $B A D$, BCL2L1, FADD, NTRK1, p53, BIRC2, BIRC3 and PDCD4, may have the potential as a predictor of invasiveness and metastatic ability of HNSCCs and thereby determining patients survival prognosis $(23,46-48)$. Since MMPs are related to ECM degradation and genes for several collagens, which are important constituents of ECM, were found to be amplified in this study the possible interaction between $M M P S$ and collagens warrants further studies.

To conclude, the results presented here provide valuable information on common chromosomal alterations possibly involved in the carcinogenesis of oral cancers. The profile of common chromosomal aberrations in the HNSCCs investigated, of which 149 genes were found located in 41 amplified regions and 28 genes in 22 deleted regions, suggests the existence of similar gene-specific alterations in the patients examined from Sudan and Norway, regardless of differences related to ethnicity and social-cultural risk factors. Hierarchical clustering of the chromosomal gains and losses found in the tumors against clinicopathological parameters showed little correlation, suggesting the occurrence of these tumors regardless of ethnic differences and clinicopathological status between the patients from the two countries.

Furthermore, cytokine-cytokine receptor interaction (calcium signaling), MAPK signaling and ECM-receptor interaction/focal adhesion/cell adhesion were found as important biological pathways involved in the pathogenesis of the cancers examined. High-level amplification of collagens, MMPs and S100A gene family members observed in the HNSCCs investigated, may provide valuable information that can be used for understanding the pathogenesis of the disease. Further studies are therefore necessary to elaborate on the role(s) of these gene family markers in HNSCCs.

\section{Acknowledgements}

The genomic microarrays were provided by the Norwegian Microarray Consortium (NMC) at the national technology platform and supported by the functional genomics programme (FUGE) in the Research Council of Norway.

\section{References}

1. Reshmi SC, Saunders WS, Kudla DM, Ragin CR and Gollin SM: Chromosomal instability and marker chromosome evolution in oral squamous cell carcinoma. Genes Chromosomes Cancer 41: 38-46, 2004.

2. Moore SR, Johnson NW, Pierce AM and Wilson DF: The epidemiology of mouth cancer: a review of global incidence. Oral Dis 6: 65-74, 2000.

3. Sankaranarayanan R, Masuyer E, Swaminathan R, Ferlay J and Whelan S: Head and neck cancer: a global perspective on epidemiology and prognosis. Anticancer Res 18: 4779-4786, 1998.

4. Franceschi S, Bidoli E, Herrero R and Munoz N: Comparison of cancers of the oral cavity and pharynx worldwide: etiological clues. Oral Oncol 36: 106-115, 2000.

5. Smith EM, Ritchie JM, Summersgill KF, Hoffman HT, Wang DH, Haugen TH and Turek LP: Human papillomavirus in oral exfoliated cells and risk of head and neck cancer. J Natl Cancer Inst 96: 449-455, 2004.

6. Cancer in Norway 2001. The Cancer Registry of Norway, 2001.

7. Idris AM, Ahmed HM and Malik MO: Toombak dipping and cancer of the oral cavity in the Sudan: a case-control study. Int J Cancer 63: 477-480, 1995. 
8. Pinkel D, Segraves R, Sudar D, Clark S, Poole I, Kowbel D, Collins C, Kuo WL, Chen C, Zhai Y, Dairkee SH, Ljung BM, et al: High resolution analysis of DNA copy number variation using comparative genomic hybridization to microarrays. Nat Genet 20: 207-211, 1998 .

9. Snijders AM, Schmidt BL, Fridlyand J, Dekker N, Pinkel D, Jordan RC and Albertson DG: Rare amplicons implicate frequent deregulation of cell fate specification pathways in oral squamous cell carcinoma. Oncogene 24: 4232-4242, 2005.

10. Bruder CE, Hirvela C, Tapia-Paez I, Fransson I, Segraves R, Hamilton G, Zhang XX, Evans DG, Wallace AJ, Baser ME, Zucman-Rossi J, Hergersberg M, et al: High resolution deletion analysis of constitutional DNA from neurofibromatosis type 2 (NF2) patients using microarray-CGH. Hum Mol Genet 10: 271-282, 2001.

11. Albertson DG: Profiling breast cancer by array CGH. Breast Cancer Res Treat 78: 289-298, 2003.

12. Singh B, Gogineni SK, Sacks PG, Shaha AR, Shah JP, Stoffel A and Rao PH: Molecular cytogenetic characterization of head and neck squamous cell carcinoma and refinement of $3 q$ amplification. Cancer Res 61: 4506-4513, 2001.

13. Bockmuhl U, Schluns K, Kuchler I, Petersen S and Petersen I: Genetic imbalances with impact on survival in head and neck cancer patients. Am J Pathol 157: 369-375, 2000.

14. Ashman JN, Patmore HS, Condon LT, Cawkwell L, Stafford ND and Greenman J: Prognostic value of genomic alterations in head and neck squamous cell carcinoma detected by comparative genomic hybridisation. Br J Cancer 89: 864-869, 2003.

15. Cawson R and Eveson J: Oral Pathology and Diagnosis (ed). Gower, London, 1987.

16. Wang J, Meza-Zepeda LA, Kresse SH and Myklebost O: M-CGH: analysing microarray-based CGH experiments. BMC Bioinformatics 5: 74, 2004.

17. Churchill GA: Fundamentals of experimental design for cDNA microarrays: Nat Genet 32: 490-495, 2002.

18. Ibrahim SO, Vasstrand EN, Johannessen AC, Idris AM, Magnusson B, Nilsen R and Lillehaug JR: Mutations of the p53 gene in oral squamous-cell carcinomas from Sudanese dippers of nitrosamine-rich toombak and non-snuff-dippers from the Sudan and Scandinavia. Int J Cancer 81: 527-534, 1999.

19. Ibrahim SO, Aarsaether N, Holsve MK, Kross KW, Heimdal JH, Aarstad JH, Liavaag PG, Elgindi OA, Johannessen AC, Lillehaug JR and Vasstrand EN: Gene expression profile in oral squamous cell carcinomas and matching normal oral mucosal tissues from black Africans and white Caucasians: the case of the Sudan vs. Norway. Oral Oncol 39: 37-48, 2003.

20. Choi $\mathrm{P}$ and Chen C: Genetic expression profiles and biologic pathway alterations in head and neck squamous cell carcinoma. Cancer 104: 1113-1128, 2005.

21. Jarvinen AK, Autio R, Haapa-Paananen S, Wolf M, Saarela M, Grenman R, Leivo I, Kallioniemi O, Makitie AA and Monni O: Identification of target genes in laryngeal squamous cell carcinoma by high-resolution copy number and gene expression microarray analyses. Oncogene 25: 6997-7008, 2006.

22. Nagatsuka H, Siar CH, Nakano K, Tsujigiwa H, Gunduz M, Choufuku H, Lee YJ, Naito I, Sado Y and Nagai N: Differential expression of collagen IV alphal to alpha6 chains in basement membranes of benign and malignant odontogenic tumors. Virchows Arch 441: 392-399, 2002.

23. de Vicente JC, Fresno MF, Villalain L, Vega JA and Hernandez Vallejo G: Expression and clinical significance of matrix metalloproteinase-2 and matrix metalloproteinase- 9 in oral squamous cell carcinoma. Oral Oncol 41: 283-293, 2005.

24. Goessel G, Quante M, Hahn WC, Harada H, Heeg S, Suliman Y, Doebele M, von Werder A, Fulda C, Nakagawa H, Rustgi AK, Blum HE, et al: Creating oral squamous cancer cells: a cellular model of oral-esophageal carcinogenesis. Proc Natl Acad Sci USA 102: 15599-15604, 2005.

25. Scully C, Field JK and Tanzawa H: Genetic aberrations in oral or head and neck squamous cell carcinoma 2: chromosomal aberrations. Oral Oncol 36: 311-327, 2000.

26. Freier K, Sticht C, Hofele C, Flechtenmacher C, Stange D, Puccio L, Toedt G, Radlwimmer B, Lichter P and Joos S: Recurrent coamplification of cytoskeleton-associated genes EMS1 and SHANK2 with CCND1 in oral squamous cell carcinoma. Genes Chromosomes Cancer 45: 118-125, 2006.
27. Veltman JA, Fridlyand J, Pejavar S, Olshen AB, Korkola JE, DeVries S, Carroll P, Kuo WL, Pinkel D, Albertson D, Cordon-Cardo C, Jain AN, et al: Array-based comparative genomic hybridization for genome-wide screening of DNA copy number in bladder tumors. Cancer Res 63: 2872-2880, 2003.

28. Bizari L, Borim AA, Leite KR, Goncalves Fde T, Cury PM, Tajara EH and Silva AE: Alterations of the CCND1 and HER-2/ neu (ERBB2) proteins in esophageal and gastric cancers. Cancer Genet Cytogenet 165: 41-50, 2006.

29. Malara NM, Leotta A, Sidoti A, Lio S, D'Angelo R, Caparello B, Munao F, Pino F and Amato A: Ageing, hormonal behaviour and cyclin D1 in ductal breast carcinomas. Breast 15: 81-89, 2006.

30. Holzmann K, Kohlhammer H, Schwaenen C, Wessendorf S, Kestler HA, Schwoerer A, Rau B, Radlwimmer B, Dohner H, Lichter P, Gress T and Bentz M: Genomic DNA-chip hybridization reveals a higher incidence of genomic amplifications in pancreatic cancer than conventional comparative genomic hybridization and leads to the identification of novel candidate genes. Cancer Res 64: 4428-4433, 2004.

31. Ibrahim SO, Lillehaug JR and Vasstrand EN: Mutations of the cell cycle regulatory genes p16INK4A and p21WAF1 and the metastasis-inducing gene S100A4 are infrequent and unrelated to p53 tumour suppressor gene status and data on survival in oropharyngeal squamous cell carcinomas. Anticancer Res 23: 4593-4600, 2003.

32. Dysvik B, Vasstrand EN, Lovlie R, Elgindi OA, Kross KW, Aarstad HJ, Johannessen AC, Jonassen I and Ibrahim SO: Gene expression profiles of head and neck carcinomas from Sudanese and Norwegian patients reveal common biological pathways regardless of race and lifestyle. Clin Cancer Res 12: 1109-1120, 2006.

33. Emberley ED, Murphy LC and Watson PH: S100 proteins and their influence on pro-survival pathways in cancer. Biochem Cell Biol 82: 508-515, 2004.

34. Wang G, Zhang S, Fernig DG, Martin-Fernandez M, Rudland PS and Barraclough R: Mutually antagonistic actions of S100A4 and S100A1 on normal and metastatic phenotypes. Oncogene 24: 1445-1454, 2005

35. Tsai ST, Jin YT, Tsai WC, Wang ST, Lin YC, Chang MT and Wu LW: S100A2, a potential marker for early recurrence in early-stage oral cancer. Oral Oncol 41: 349-357, 2005.

36. Mueller A, Schafer BW, Ferrari S, Weibel M, Makek M, Hochli $\mathrm{M}$ and Heizmann CW: The calcium-binding protein S100A2 interacts with p53 and modulates its transcriptional activity. J Biol Chem 280: 29186-29193, 2005.

37. el-Naggar AK, Hurr K, Batsakis JG, Luna MA, Goepfert H and Huff V: Sequential loss of heterozygosity at microsatellite motifs in preinvasive and invasive head and neck squamous carcinoma. Cancer Res 55: 2656-2659, 1995.

38. Huang X, Gollin SM, Raja S and Godfrey TE: High-resolution mapping of the $11 \mathrm{q} 13$ amplicon and identification of a gene, TAOS 1, that is amplified and overexpressed in oral cancer cells. Proc Natl Acad Sci USA 99: 11369-11374, 2002.

39. Akervall JA, Michalides RJ, Mineta H, Balm A, Borg A, Dictor MR, Jin Y, Loftus B, Mertens F and Wennerberg JP: Amplification of cyclin D1 in squamous cell carcinoma of the head and neck and the prognostic value of chromosomal abnormalities and cyclin D1 overexpression. Cancer 79: 380-389, 1997.

40. Michalides R, van Veelen N, Hart A, Loftus B, Wientjens E and Balm A: Overexpression of cyclin D1 correlates with recurrence in a group of forty-seven operable squamous cell carcinomas of the head and neck. Cancer Res 55: 975-978, 1995.

41. Hsu LC, Huang X, Seasholtz S, Potter DM and Gollin SM: Gene amplification and overexpression of protein phosphatase 1 alpha in oral squamous cell carcinoma cell lines. Oncogene 25: 5517-5526, 2006.

42. Baldwin C, Garnis C, Zhang L, Rosin MP and Lam WL: Multiple microalterations detected at high frequency in oral cancer. Cancer Res 65: 7561-7567, 2005.

43. Li C, Chen L and Chen J: DNA damage induces MDMX nuclear translocation by $\mathrm{p} 53$-dependent and -independent mechanisms. Mol Cell Biol 22: 7562-7571, 2002.

44. Danovi D, Meulmeester E, Pasini D, Migliorini D, Capra M, Frenk R, de Graaf P, Francoz S, Gasparini P, Gobbi A, Helin K, Pelicci PG, et al: Amplification of Mdmx (or Mdm4) directly contributes to tumor formation by inhibiting p53 tumor suppressor activity. Mol Cell Biol 24: 5835-5843, 2004. 
45. Thomas GT, Lewis MP and Speight PM: Matrix metalloproteinases and oral cancer. Oral Oncol 35: 227-233, 1999.

46. Patel BP, Shah SV, Shukla SN, Shah PM and Patel PS: Clinical significance of MMP-2 and MMP-9 in patients with oral cancer. Head Neck (In press).

47. Baker EA, Leaper DJ, Hayter JP and Dickenson AJ: The matrix metalloproteinase system in oral squamous cell carcinoma. Br J Oral Maxillofac Surg 44: 482-486, 2006.

48. Zhang Y, Wang C, Mizukami H, Itoh H, Kusama M, Ozawa K and Jinbu Y: Increased expression and activation of matrix metalloproteinase-2 (MMP-2) in $\mathrm{O}-1 \mathrm{~N}$ : hamster oral squamous cell carcinoma with high potential lymph node metastasis. J Exp Clin Cancer Res 25: 417-423, 2006.
49. Meza-Zepeda LA, Kresse SH, Barragan-Polania AH, Bjerkehagen B, Ohnstad HO, Namløs HM, Wang J, Kristiansen BE and Myklebost O: Array comparative genomic hybridization reveals distinct DNA copy number differences between gastrointestinal stromal tumors and leiomyosarcomas. Cancer Res 66: 8984-8993, 2006. 